\title{
Do Apolo de Belvedere ao Guerreiro Tupinambá: Etnografia e convenções renascentistas ${ }^{1}$
}

\author{
Yobenj Aucardo Chicangana-Bayona*
}

\section{Resumo:}

O artigo começa com a apresentação da Coleção Grandes Viagens iniciada por Theodoro de Bry (1528-1598), para em sua segunda parte, analisar o alcance etnográfico e a aplicação da teoria da arte renascentista nas gravuras da Americae Tertia Pars (1592) sobre os índios Tupinambá.

Palavras-chave: Tupinambá, Theodoro de Bry, gravuras, Renascimento, Grandes Viagens, americae tertia pars, etnografia, cânones clássicos.

Este artigo parte de uma questão básica, por que os índios são representados nas gravuras do século XVI com corpos escultóricos? Assim, este texto analisa a teoria da arte da renascença, o alcance etnográfico e a influência dos cânones artísticos nas posturas e proporções dos tupinambás da Americae Tertia Pars (1592), que ajudarão a entender o corpo do índio como categoria universal, e não como um indivíduo em particular. Para isso é importante apresentar a obra na que esta reflexão se baseia.

\section{Theodoro de Bry e suas “Grandes Viagens"}

O flamengo reformado, Theodoro de Bry (1528-1598), publicaria a Admiranda Narratio, ${ }^{3}$ em 1590, obra dedicada à primeira viagem inglesa à Virgínia em 1585. Era o início da coleção Thesaurus de Viagens ou Collectionnes Peregrinatorum in Indiam Occidentalem et Indian Orientalem, mais conhecida popularmente como As Grandes Viagens e as Pequenas Viagens.

As Grandes Viagens são dedicadas às narrativas do Novo Mundo, compondo ao todo 13 volumes publicados entre 1590 e 1634, e às Pequenas Viagens dedicadas às Índias Orientais formadas também por 13 partes.

O segundo volume a Secvnda Pars Americae ou Brevis Narratio de 1591, foi baseado no diário do capitão Laudonnière sobre a expedição francesa de 1565 à Flórida (1992).

A terceira parte, a Americae Tertia Pars publicada em 1592, está baseada nas narrativas do alemão Hans Staden e do francês Jean de Léry sobre as viagens ao Brasil - 
conhecido nessa época como França Antártica - e os habitantes destas terras, os tupinambá.

Durante sua vida De Bry publicaria seis partes da gigantesca coleção (15901596), no momento de sua morte, em 1598, a sétima parte não chegou a ficar pronta. Seus sucessores, Johan Theodor e Johan Israel, publicariam as partes 7, 8 e 9 (15981601). Depois da morte de Johan Theodor, Matthäus Merian publicaria as últimas quatro partes 10 a 13 entre 1619 e 1634.

As Grandes Viagens como também outras coleções sobre narrativas de viagem exerciam um atrativo, fascinavam e geravam curiosidade tanto nas elites como no resto da população. Ao mesmo tempo ajudaram a impulsionar a colonização das Novas Terras e iniciar empreendimentos comerciais (Bucher, 1981, p.11).

Porém a coleção editada em vários volumes por Theodoro de Bry e seus descendentes não servia só para o deleite do leitor, mas também para incitar a meditação sobre a bondade e a misericórdia de Deus, além dos "ensinamentos que se podiam tirar do espetáculo de povos infelizes e bárbaros" (Del Priore, 2000, p.82; Baumann, 2001, p.259). Aqui incluídos estão a propagação do evangelho e o fortalecimento da posição protestante (Baumann, 2001)

O gigantesco projeto editorial das Grandes Viagens formaria parte de um novo tipo de edições que, ao final do século XVI, se caracterizavam por serem bem cuidadas, feitas em menor tempo e com uma maior qualidade e apuro, tanto das gravuras, agora feitas em metal, como de melhores técnicas de reprodução e impressão (Luins, 1982, p.160; Mukerji, 1983, p.65; Eisenstein, 1998, p.38-41). A melhoria na qualidade das ilustrações proporcionou que estas tivessem grande destaque e que não fossem apenas meros complementos dos textos. Os livros ilustrados ganharam maior difusão e converteram-se em um método sofisticado de comunicação, não só para ajudar a simples leitura de semi-analfabetos, mas agora também para atender à demanda de uma elite cultural (Mukerji, 1983, p.66).

Se a Imprensa gerou um processo de transformações na escrita, a gravura vai gerar uma "revolução" no uso da imagem na Europa dos séculos XV e XVI. A imprensa e os diferentes tipos de gravuras promoveram um grande desenvolvimento, já que permitiram, não somente reproduzir infinidade de cópias a partir de um original, como também reduzir o tempo para isso ser conseguido.

O impacto que a imprensa gerou na Europa, bem como sua popularização, ${ }^{4}$ fizeram que a gravura também fosse utilizada como veículo de "propaganda" tanto 
pelos protestantes como pelos católicos 5 . O protestantismo foi pioneiro em explorar o potencial da imprensa como meio de massa (Eisenstein, 1998, p.167). Por outro lado, o Concílio de Trento, no século XVI, estipularia o uso de imagens para a ação evangelizadora católica.

É no contexto de guerras religiosas e expansão atlântica que se inserem os primeiros volumes da coleção de Theodoro de Bry, que tinham, entre outras funções, o estímulo do comércio, a colonização do Novo Mundo e a difusão do cristianismo, além de sensibilizar a rainha Elizabeth I para retomar o projeto de colonização da Virginia interrompido em 1588 (Bucher, 1981, p.7; Baumann, 2001, p.248).

\section{Figurar um Tupinambá}

Na sua Viagem à Terra do Brasil, Jean de Léry (1578) faz uma interessante descrição para o leitor sobre "como figurar um Tupinambá". Esta descrição pode nos dar as ferramentas para entender a conformação dos corpos dos índios nas gravuras posteriores de Theodoro de Bry,

Se quiserdes agora figurar um índio, bastará imaginardes um homem nu, bem conformado e proporcionado de membros, inteiramente depilado, de cabelos tosquiados como já expliquei, com lábios e faces fendidos e enfeitados de ossos e pedras verdes, com orelhas perfuradas e igualmente adornadas, de corpo pintado, coxas e pernas riscadas de preto com o suco de jenipapo, e com colares de fragmentos de conchas pendurados ao pescoço. Colocai-lhe na mão seu arco e suas flechas e o vereis retratado bem garboso ao vosso lado. Em verdade, para completar o quadro, devereis colocar junto a esses tupinambás uma de suas mulheres, com o filho preso a uma cinta de algodão e abraçando-lhe as ilhargas com as pernas... (Léry, 1980, p.118)

Uma das xilogravuras que acompanha a edição de Viagem à Terra do Brasil de Jean de Léry foi feita a partir do anterior trecho. Como também acontece com o tupinambá do frontispício da Americae Tertia Pars de Theodoro de Bry que segue à risca as indicações da descrição do francês na sua obra. A citação de Léry revela o alcance da etnografIa do século XVI, ...o homem nu e bem proporcionado..., corresponde a uma categoria universal de um corpo idealizado, enquanto os distintivos: lábios com pedras, orelhas perfuradas, corpo pintado extremidades riscadas, cabelo tosquiado, arco e flechas, seriam o distintivo individual (fig.1). 

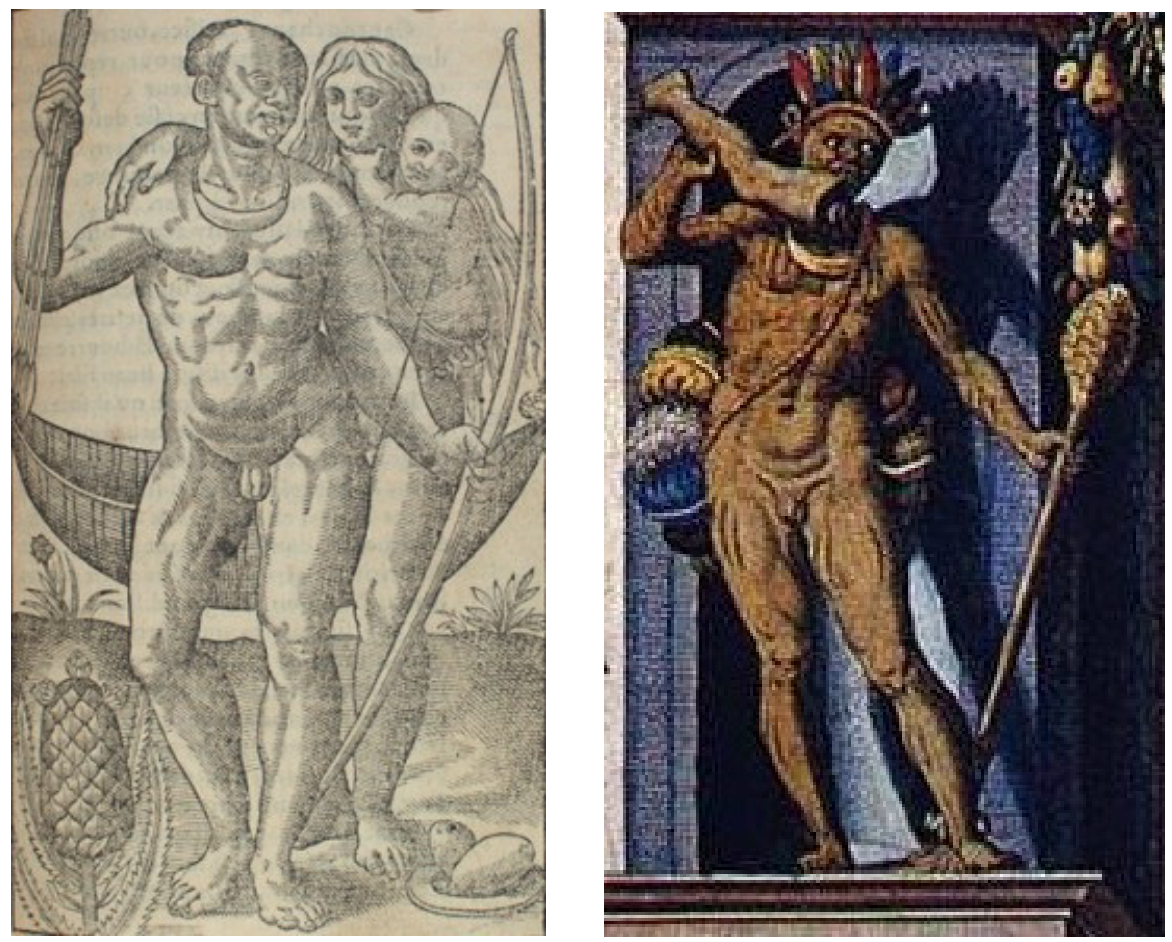

Figura 1. Esquerda: Família de Tupinambás. Jean de Léry. Histoire d'une voyage fait en la terre du Bresil. Autrement Dite Americque... 4.ed. Genebra, Heritiers D’Eustache Vignon. Xilogravura 14 x 18 cm, 1600. Direita: Detalhe índio tupinambá do Frontispício. Theodoro de Bry. Americae Tertia Pars, gravura, 1592.

Os critérios de diferenciação racial convencionalmente estavam estabelecidos pela cor da pele, não por diferenças de biotipo. Essas diferenças raciais por meio da cor passam a não serem percebidas nas gravuras, já que estas eram monocromas indo do preto da tinta até o branco do papel. Apesar de existir o recurso da gravura pintada ou colorida artesanalmente que permitia ainda manter as convenções raciais por meio da cor, mas a grande maioria das gravuras eram em preto e branco, como Bucher ressalta: "...Thus the use of black and white causes the disappearance of one criterion for the racial and racist differentiation that later develops in América: skin color ..." (Bucher, 1981, p.35).

Comparando uma mesma gravura colorida artesanalmente e outra só em preto e branco, no caso, a estampa Preparo da carne humana no moquém (fig.2), a imagem colorida diferencia tons de pele mais acastanhados ou avermelhados para os Tupinambá e uma pele mais branca e pálida em Hans Staden. Na imagem monocroma essa diferenciação das cores se perde, sem ser possível diferenciar ameríndio e europeu, precisamente pela falta de diferenças étnicas e de biotipo. As principais diferenças entre o alemão Staden e os índios Tupinambás são estabelecidas não só através dos cortes de 
cabelo, o uso da barba, artefatos e indumentárias, mas também pelos gestos e comportamentos ${ }^{6}$.

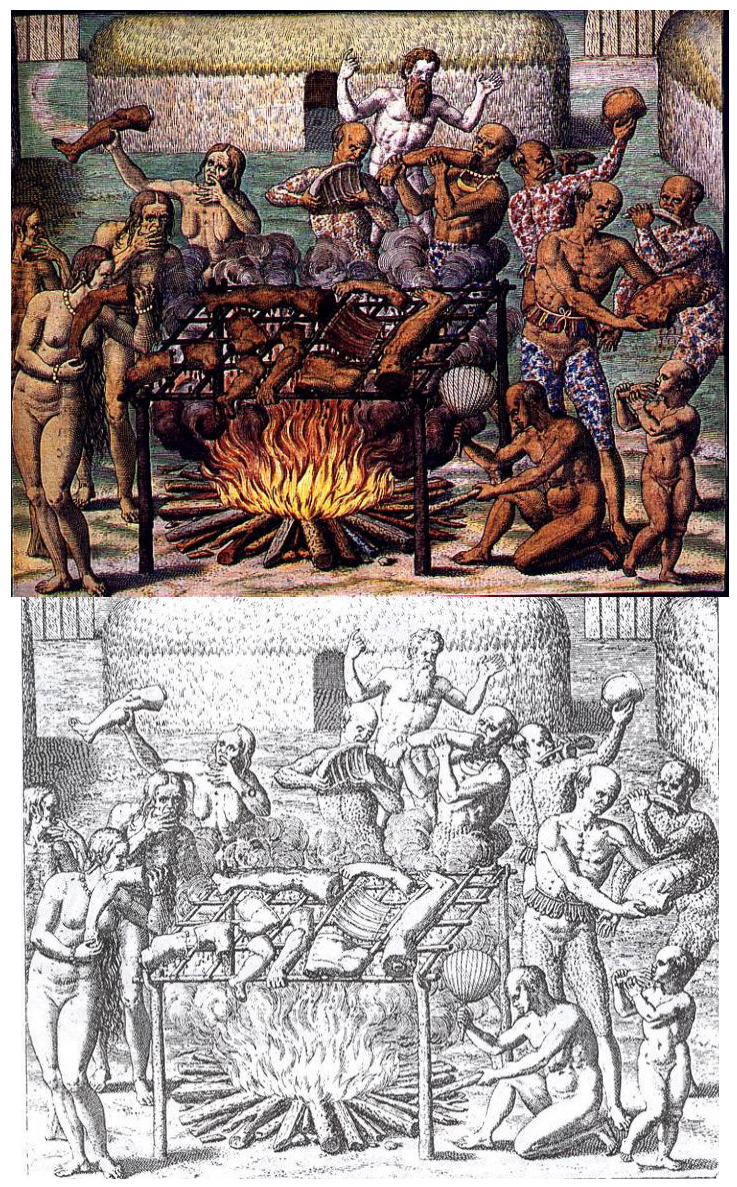

Figura 2. Detalhes gravura colorida artesanalmente e gravura monocroma. Theodoro de Bry, Preparo da carne humana no moquém. America Tertia Pars. Gravura em cobre, Frankfurt, 1592.

No caso da gravura colorida fica fácil identificar Staden dos índios, pois ele ressalta com a pele branca, o nu, o cabelo e barba ruiva. ${ }^{7} \mathrm{O}$ contraste das imagens acontece pela cor da pele mais escura e avermelhada dos tupinambás, seus gestos grotescos e o tosquiado de seus cabelos; são elementos convencionados no século XVI, como diferenciais entre o europeu e os ameríndios.

No entanto, se forem abstraídas tais diferenças, bem como a distração que possam causar as cores, pode-se perceber que os corpos são similares, sempre com um tratamento escultórico, torneados, musculosos; tanto de Staden como dos índios. Mas as similitudes não param aí, os rostos tanto em Hans Staden como nos Tupinambás é resolvido da mesma forma, ou seja, os olhos e o nariz não têm diferenças, parecendo o 
mesmo modelo. Apenas a barba que identificaria o europeu e as caretas grotescas dos índios, mas, em princípio, o esquema de representação não muda, mudam os detalhes de cada "manequim".

Realizei uma experiência a partir de uma imagem de Hans Staden e de um guerreiro tupinambá com arco ao seu lado, na gravura em que aparecem as mulheres escaldando o corpo da vítima (fig.3A). Na primeira interferência apaguei os rostos e os detalhes de cada personagem: barbas, cabelos compridos, arco, flecha, cocar, deixando só os corpos de Staden e do Tumpinambá (fig.3B). Na terceira imagem intercambiei os elementos distintivos de um e de outro; barba, bigode e sobrancelhas passaram para o índio, enquanto cocar, penas, pedras no rosto, arco e flechas passaram para Hans Staden (fig.3C). A conclusão é que, anatomicamente, os corpos do Europeu e o do Índio são iguais, seguindo o mesmo cânone; as distinções entre os dois é dada pelas características dos ornamentos e da indumentária.

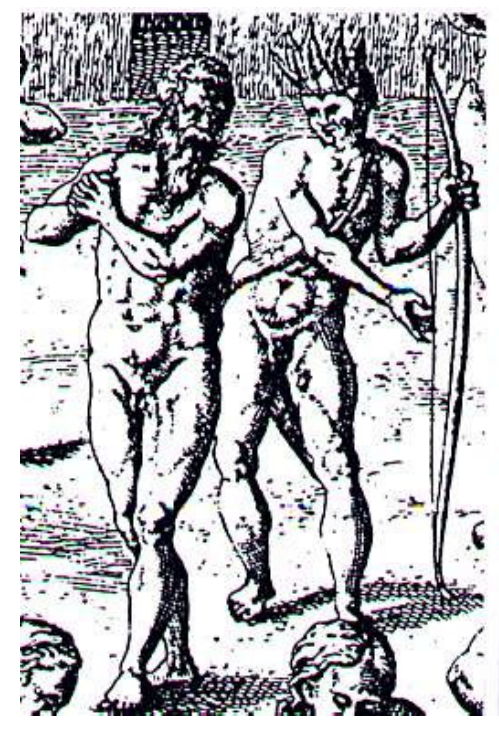

A.

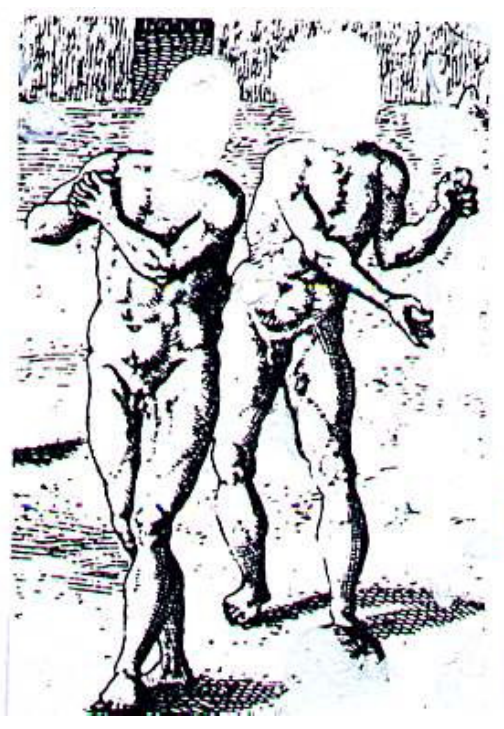

B.

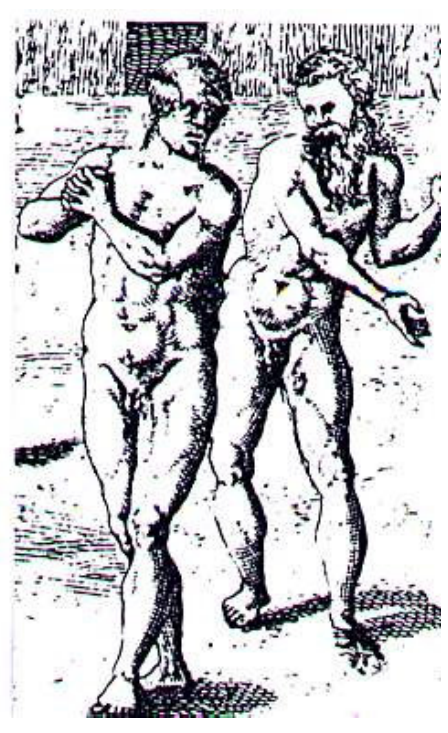

C.

Figura 3. Detalhe de Hans Staden e guerreiro tupinambá. A. Gravura original; B. Primeira interferência: são apagados rostos e distintivos deixando só os corpos de Staden e do Tupinambá; C. Segunda interferência: Os artefatos e enfeites do Tupinambá são passados a Staden, ao tempo que a barba e os cabelos longos distintivos de Staden passam ao Tupinambá. Theodoro de Bry, Mulheres preparando o corpo da vitima. America Tertia Pars. Gravura em cobre, Frankfurt, 1592.

Uma analogia que pode ajudar a entender as figuras de De Bry é a idéia de um "manequim" ao qual são adaptados elementos para diferenciar suas particularidades, 
que, no caso de Staden, correspondem aos cabelos compridos, às barbas e ao índio: o cabelo tosquiado "similar ao dos frades", o cocar de penas, arco e flechas.

Nas cenas do repasto antropofágico aparece mais um diferencial entre o europeu e o índio; estou me referindo aos gestos agressivos no rosto dos tupinambás, que contrastam nas gravuras com o semblante sereno de Staden. Estes gestos grotescos não correspondem a diferenças de biótipo como se possa pensar. Na verdade, os gestos e movimentos corporais são a forma que De Bry encontra para externar as paixões internas dos índios, o sentimento de vingança contra o inimigo que eles estão devorando; tal como anotava Alberti com relação às figuras pintadas ou desenhadas no século XV: “

Cada um, pois, com dignidade, tenha os movimentos do corpo para exprimir todos os movimentos desejados da alma e, para as grandes perturbações da alma, sejam proporcionais os grandes movimentos dos membros... 8

A noção de etnografia do século XVI estava baseada em roupas, adornos, artefatos, enfeites que os indivíduos usavam, isto é, nos detalhes externos. São esses últimos detalhes que induzem a acreditar em um "retrato" de índios (Mason, 1998, p.46).

Já no século XVI os artistas europeus conheciam e reproduziam os artefatos que chegavam às suas mãos do Novo Mundo com certa exatidão, colocando-os ao lado de figuras "clássicas" que não tinham muito a ver com aborígenes. Obras famosas de índios como as de Dürer e Burgkmair demonstravam que o artista conhecia os artefatos, mas não seu funcionamento ou uso. Às vezes a qualidade dos detalhes de tais artefatos levantava a dúvida da veracidade de que estes artistas tenham realmente visto estes índios em seu natural.

Desse modo, indaga-se a razão de este tipo de corpo musculoso "padrão" ter sido usado nas gravuras, a explicação encontra-se na filosofia neoplatônica. Para Platão o universal era a idéia, algo além em um mundo inteligível, daí o real, isto é, a natureza, era uma imitação, uma cópia imperfeita da idéia. Por sua vez, a arte seria uma cópia da natureza e por ser uma cópia da cópia era ainda mais degradada e imperfeita. Em seus Ensaios Montaigne cita que “... Tôdas as coisas, disse Platão, produzem-nas a natureza ou o acaso, ou a arte. As mais belas e grandes são frutos das duas primeiras causas; as menores e mais imperfeitas, da última..."

Essa degradação sob a ótica de Platão tirava a validade da arte. A partir destes mesmos fundamentos, o neoplatonismo resgatava o artista como um ser especial e 
diferente do resto dos mortais, e por ter uma sensibilidade, ele podia corrigir tais falhas da natureza e aproximar-se mais da idéia, como ressalta Gio Pietro Bellori no século XVII:

Mas os corpos celestes que estão acima da Lua não estão sujeitos à mudança, e permanecerão eternamente belos, e ordenados, tal como podemos sempre vê-los na harmonia de suas esferas e no esplendor de sua aparência. Os corpos sublunares, ao contrário, estão submetidos à mudança e à feiúra: e ainda que a Natureza tenda sempre a produzir efeitos excelentes, por causa da desigualdade da matéria, as formas se alteram, e particularmente a beleza humana, como podemos ver nas múltiplas deformidades e desproporções que estão em nós. Por isso os nobres Pintores e Escultores, imitando o primeiro Operário, formam igualmente em seus espíritos um modelo de beleza superior e, sem afastá-lo dos olhos, emendam a natureza corrigindo suas cores e suas linhas... (Bellori, in: Panofsky, 2000. Apêndice II, p.143-4)

$\mathrm{O}$ artista poderia emendar e corrigir as imperfeições da natureza por ser especial.

Esse 'dom' estabelecia a função e a missão do artista na Renascença como assinala corretamente o professor Gombrich:

... o pintor, ao contrário dos mortais comuns, é uma pessoa que tem o dom divino de perceber não o mundo imperfeito e evasivo dos indivíduos, mas os próprios arquétipos na sua eternidade. Cabe-lhe purificar o mundo da matéria, obliterar suas falhas e aproximá-lo da idéia. Ele é auxiliado nisso pelo conhecimento das leis da beleza, que são as de afinidades geométricas, harmoniosas e singelas, e pelo estudo daquelas antiguidades que já representam realidade "idealizada", isto é, semelhante à idéia platônica ... (Gombrich, 1995, p.166)

Por isso, ao seguir as idéias do neoplatonismo ${ }^{10}$ de Marsilio Ficino (1433-1499), os renascentistas acreditavam que a beleza perfeita não poderia ser encontrada em um só corpo, e sim dispersa em vários indivíduos, como tinha sido demonstrado no episódio vivido pelo famoso artista grego Zeuxis, que, para fazer sua versão de Helena, não escolheu uma mulher só, mas procurou a beleza em várias, ou melhor, cinco virgens, como ressalta Alberti:

Zêuxis, o mais ilustre e competente de todos os pintores ... não confiou imprudentemente em seu próprio engenho, como fazem hoje os pintores. Como pensava ele não ser possível encontrar em um só corpo toda a beleza que procurava - coisa que a natureza não deu a uma só pessoa -, escolheu as cinco moças mais belas de toda a juventude daquela terra, para delas tirar toda a beleza que se aprecia numa mulher ... (Alberti, 1989, liv.II, 56, p.133)

De acordo com os artistas da Renascença, a beleza ideal não estava distanciada do mundo natural, mas encontrava-se dispersa nele; e o artista, com sua sensibilidade e 
intelecto, teria a capacidade de reunir e gerar a beleza ideal. Desse esforço resultaram os famosos cânones. Um corpo ideal seria então constituído pelo melhor da natureza, como assinala Moshe Barasch:

El artista no debe aceptar el objeto o figura tal y como se lo encuentra por azar. La verosimilitud en sí misma no basta; conseguir una ilusión convincente del cuerpo natural no es suficiente. Al objeto o a la figura representada hay que infundirle armonía a través de un modelo de validez eterna (belleza), y los modelos bellos tienen que ser extraídos de la naturaleza. La imitación de la naturaleza revisada es la base y el pensamiento esencial de la teoría renacentista del arte... (Barasch, 1999, p.110)

O cânone seria o caminho para corrigir as falhas da natureza e aproximá-la da idéia. Nesse sentido, o cânone deve ser entendido como um conjunto das relações que regulam as diferentes proporções das partes da obra, conforme a um modelo acabado, o ideal de beleza. Segundo Gombrich, “... sabemos que nome os antigos davam às suas schematas; referiam-se a elas como o cânon, isto é, as relações básicas, geométricas, que o artista tem de conhecer para a construção de uma figura plausível..." (Gombrich, 1995, p.157).

É importante anotar aqui que a teoria das proporções na Renascença não era um simples expediente técnico, mas um postulado metafísico, como afirma Erwin Panofsky:

A teoria das proporções humanas era vista tanto como um requisito da criação artística quando como uma expressão de harmonia preestabelecida entre o microcosmo e o macrocosmo; além do mais, era vista como a base racional para a beleza. Podemos dizer que a Renascença fundia a interpretação cosmológica da teoria das proporções, corrente nos tempos helenísticos e na Idade Média, com a noção clássica da "simetria" como princípio fundamental da perfeição estética ... (Panofsky, 2002, p.129)

A existência de um tipo de cânone de beleza perfeita derivava de Alberti, que, baseado em Marco Vitruvio, considerava a variedade como valor artístico, e não a possibilidade de variedades de beleza.

Um dos seguidores dos preceitos de Alberti foi Albrecht Dürer ${ }^{11}$, que, depois da sua viagem à Itália ficou muito influenciado com a arte clássica, e ao longo de repetidas tentativas para "extrair da natureza" um cânone de proporções perfeitas, chegou à conclusão de que existiam diversos tipos humanos que podia se atribuir beleza:

Pero la belleza está presente entre los hombres de tal forma y nuestro juicio sobre ella es tan inseguro que podemos, quizá, encontrar dos hombres, ambos bellos y hermosos, y observar, sin embargo, que ninguno se parece al otro, ni en medidas ni en tipo, ni en un solo punto o parte ... (The Writings of Albrecht Dürer, p.248, apud Barasch, 1999, p.127) 
Na Della Simmetria dei Corpi Humani, Dürer estabelece que não existe um só cânone de beleza ideal para um homem ideal, mas diferentes tipos de cânones, porque na natureza existem diferentes tipos humanos de beleza, jovens e adultos, fortes e grandes, negros e brancos, homens e mulheres, baixas, gordas, velhas, magras, jovens. A vocação de teórico ${ }^{12}$ faria que Dürer estabelecesse diferentes cânones, que depois seriam assimilados pelos artistas nas décadas seguintes. Sobre Dürer, assinala Panofsky:

Mas sobrepujou os dois grandes italianos [Alberti e Leonardo] não apenas pela variedade e precisão de suas medidas, mas também por uma auto-limitação genuinamente crítica. Renunciando, firmemente, à ambição de descobrir um cânone ideal de beleza, entregou-se à tarefa infinitamente mais laboriosa de estabelecer vários tipos "característicos" os quais - cada um a seu modo "evitassem a feiúra grosseira". Acumulou nada menos que vinte e seis conjuntos de proporções, além de um exemplo de corpo de criança e as medidas detalhadas da cabeça, pé e mão. Não satisfeito com isso, indicou maneiras e modos de variar ainda mais esses vários tipos para captar mesmo o grotesco e o anormal por métodos estritamente geométricos ... (Panofsky, 2002, p.140-2).

A difusão dos cânones permitia que artistas resolvessem rapidamente uma composição. Esses cânones se convencionaram como modelos para representar qualquer tipo humano e tiveram grande acolhida por toda Europa. Os cânones estabelecidos por Dürer encontram-se tanto nos índios de Léry como nos de Theodoro De Bry.

Isso pode ser comprovado ao se comparar um dos cânones Della Simmetria dei Corpi Humani de Dürer com uma das xilogravuras de índios do relato de Léry de 1600 (fig.4). Até as sombras que dão volume ao corpo do Tupinambá seguem as linhas do esquema. A influência de Dürer também pode ser notada em uma Eva estilizada de Theodoro De Bry da Admiranda Narratio, muito similar a um dos cânones de mulher do alemão (fig.5). 

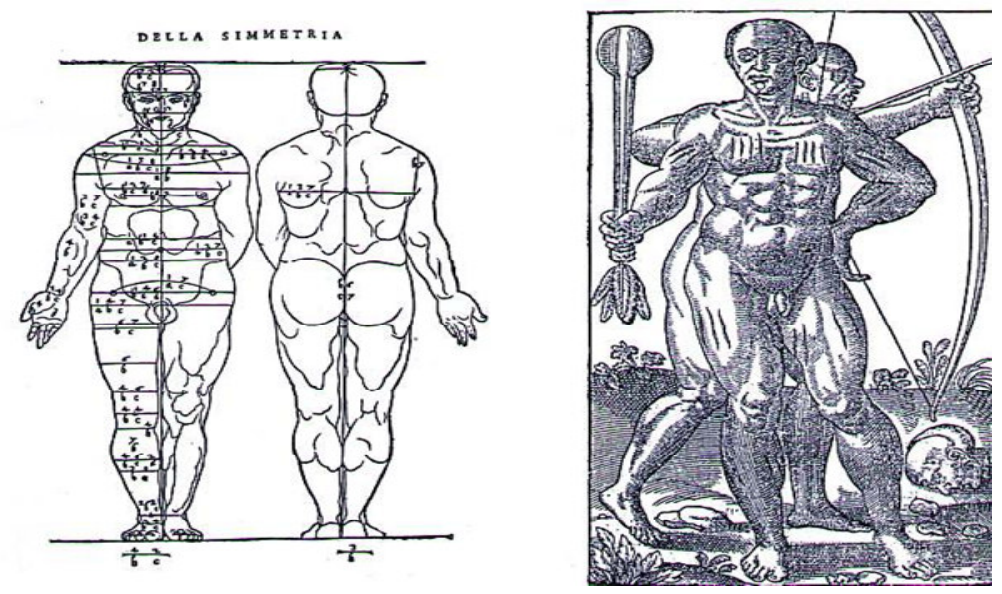

Figura 4. Esquerda: Homem forte frente e verso fol 31 v. Alberti Dvreri. Clarissimi Pictoris et Geometrae de Symmetria partium humanorum corporum. Liber Secvdus, tinta sobre papel, Paris, 1557. Direita: Índios Tupinambás Guerreiros. Jean de Léry. Histoire d'une voyage fait en la terre du Bresil. Autrement Dite Americque... 4.ed. Genebra, Heritiers D’Eustache Vignon. Xilogravura 14 x 18 cm, 1600.
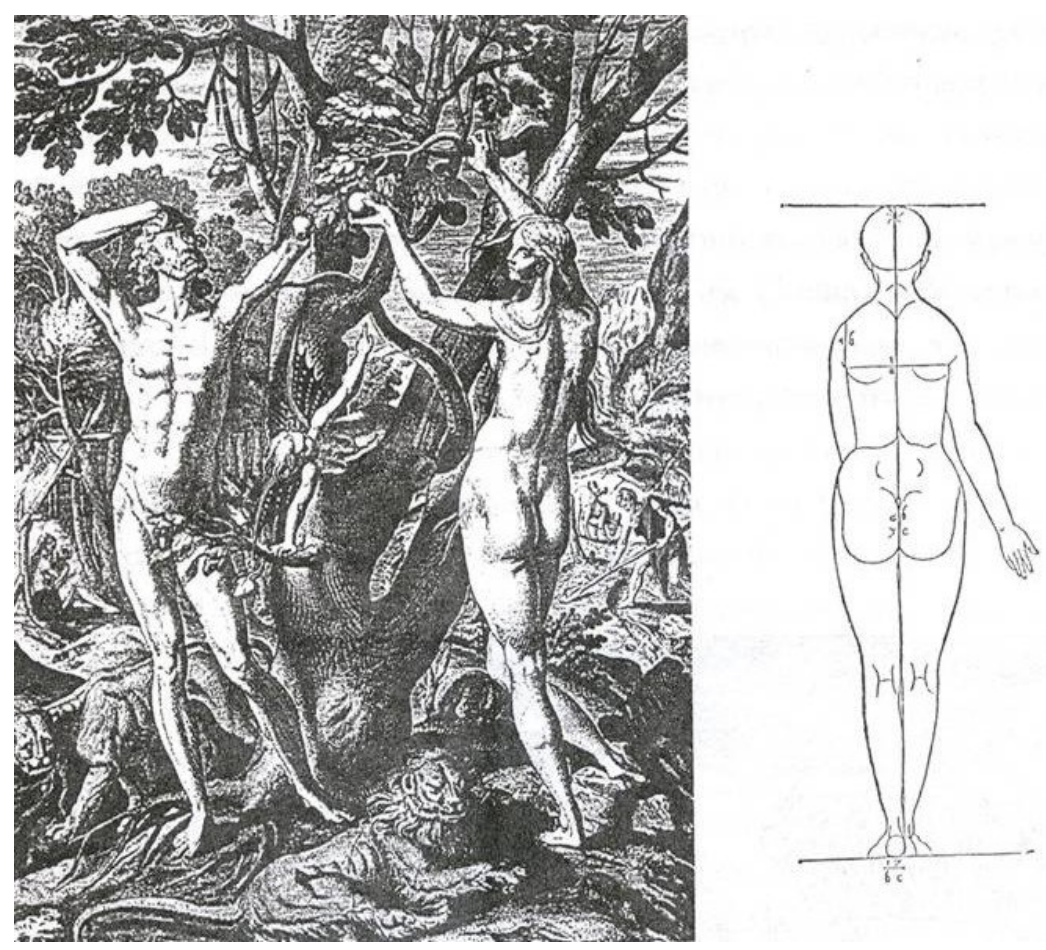


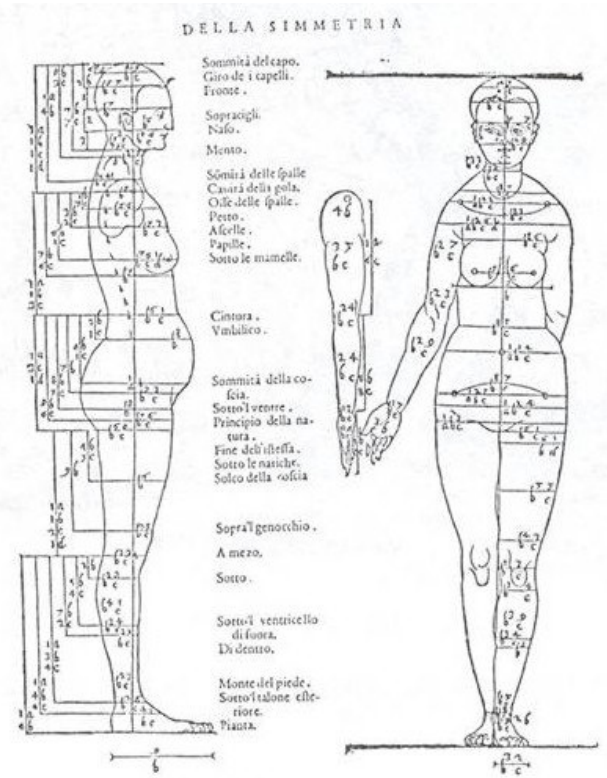

Figura 5. Esquerda superior: Adão e Eva. Theodoro De Bry. Admiranda Narratio, Grandes Viagens, gravura, 1590. Direita superior: mulher verso fol 42, Abaixo: mulher perfil e frente fol. 41v. Alberti Dvreri. Clarissimi Pictoris et Geometrae de Symmetria partium humanorum corporum. Liber Secvdus, tinta sobre papel, Paris, 1557.

Não apenas o corpo respondia a determinados cânones de representação preestabelecidos; também as ações do corpo e a postura. Em uma gravura sobre uma das viagens dos franceses à Flórida, feita por Theodoro De Bry para o segundo volume das Grandes Viagens, a Secvnda Pars Americae ou Brevis Narratio de 1591, está representada uma batalha entre o rei Holata Outina e seu inimigo o rei Satourioua. Graças ao auxílio dos franceses, que na estampa aparecem nos flancos da formação do exército de Outina, acaba alcançando a vitória (fig.6). 


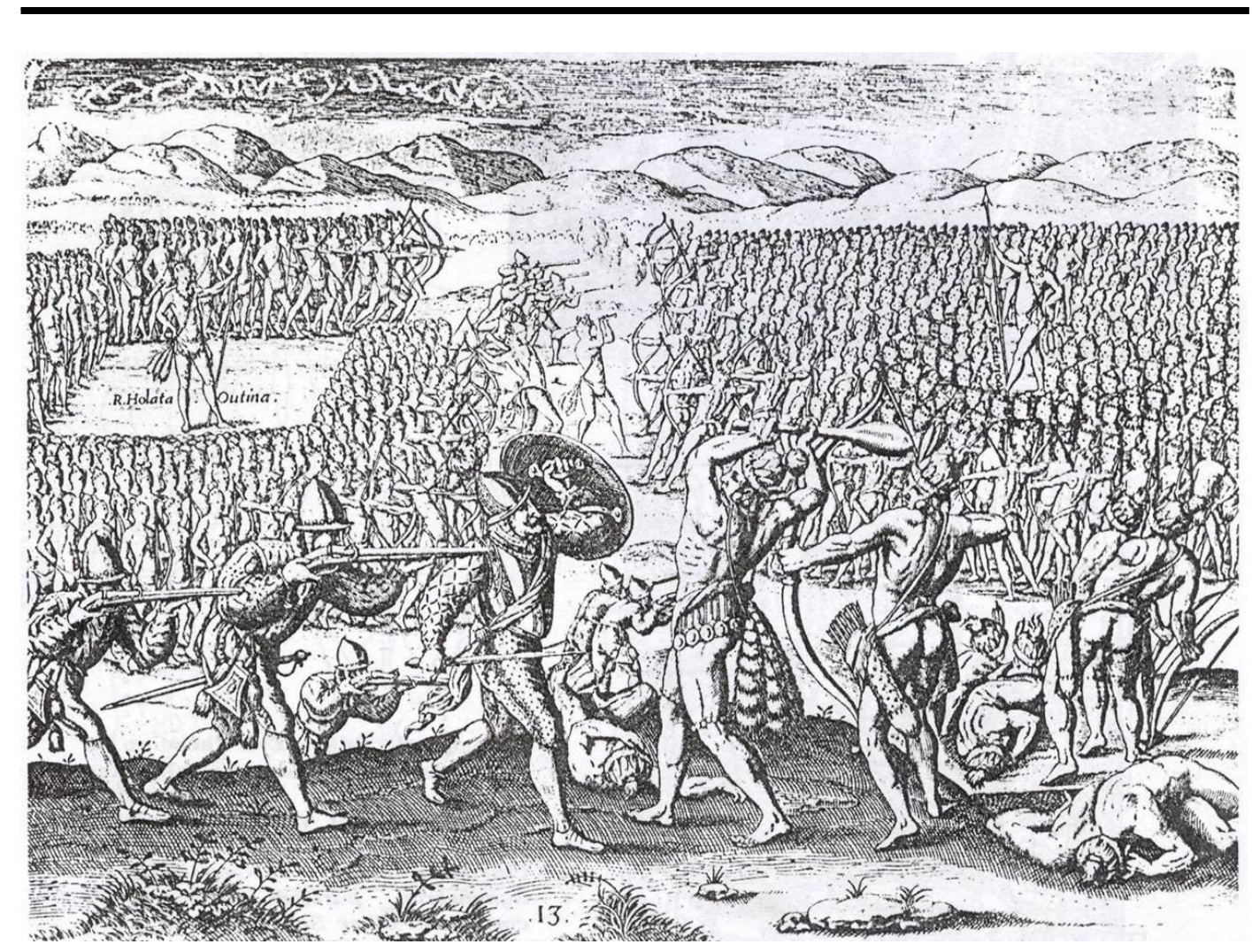

Figura 6. Theodoro De Bry. Outina Gallorum auxilio Potanou fuum hoftem fuperar. Brevis Narratio, Gravura, 1591.

A gravura apresenta, nos planos de fundo, o embate dos dois exércitos comandados pelos seus respectivos reis. Nos primeiros planos, nativos enfrentam franceses com armas de fogo. Naturalmente, o exército do rei Satourioua é mais numeroso, ocupando a metade da gravura, o que visualmente justificaria o papel fundamental que lançaram os franceses ao auxílio do rei e de sua posterior vitória. No centro da batalha, as duas forças marcham ao embate em prontidão com seus arcos e flechas.

No meio de cada exército aparecem os dois reis de corpo completo, em uma postura destacada, com um braço recolhido contra a cintura e o outro estendido, apoiado em uma espécie de lança. O rei Outina tem um pé na frente do outro, parecendo ficar em uma posição de espera; a perna que fica atrás suporta o peso do corpo. O rei Satourioua aparece em posição similar, só que em movimento, parecendo avançar. Esta postura denota nobreza, elegância e, por que não, um certa arrogância e desafio, já que na gravura só os dois reis adotam tal postura.

Em outra gravura de De Bry, desta vez sobre os índios Tupinambá do Brasil (fig.7 esquerda), encontra-se uma postura similar à dos reis índios da Flórida. Neste 
caso, o guerreiro Tupinambá armado com uma ibirapema, que acabou de acertar um índio cujo corpo jaz no chão, adota também esta posição (Staden, 1930, p.188-90 \& Léry, 1980, p.196-8). O braço direito aparece dobrado em ângulo, descansando sobre a cintura, enquanto o braço esquerdo, levemente levantado, empunha o tacape que repousa nos ombros do guerreiro. O peso do corpo está sustentado pela perna esquerda, enquanto a perna direita está levemente estendida para a direita.

No frontispício da Americae Pars Quarta, dedicado aos índios do Peru e México, novamente a mesma postura é repetida no rei índio da parte inferior direita (fig.7 direita). Uma conclusão apressada poderia levar à afirmação de que esta postura, presente em várias gravuras de diferentes etnias, seria uma convenção para representar personagens de reis, chefes ou líderes. Porém, em outras imagens, esta postura é repetida não só nos reis, mas em guerreiros índios e soldados europeus.
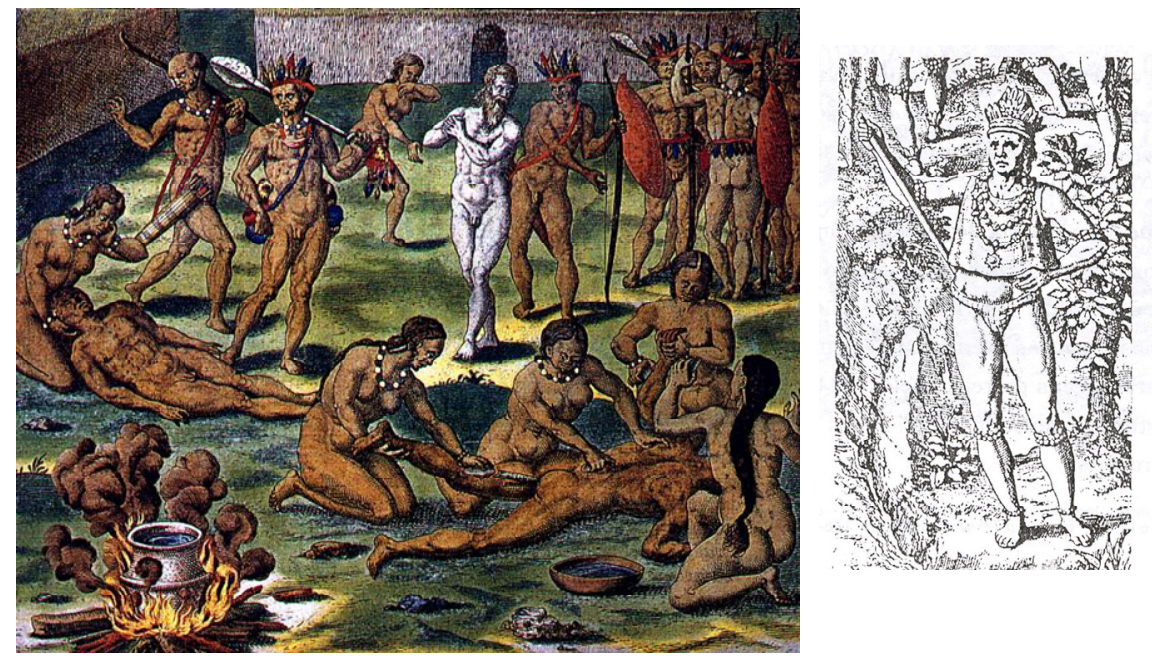

Figura 7. Esquerda: Theodoro De Bry. Hans Staden assiste à preparação do corpo. Americae Tertia Pars, Gravura, 1592. Direita: Theodoro De Bry. Detalhe do Frontispício da Americae Pars Quarta, Gravura, 1594.

A insistência nesta postura pode ser encontrada nas próprias séries de estampas feitas por De Bry sobre o rei Holata Outina da Flórida, e dos franceses que lá estiveram (fig.8). Na gravura, percebe-se a presença do rei na parte esquerda da composição, adotando a postura em questão, enquanto está rodeado pelas mulheres dos 
guerreiros. Nos planos de fundo aparecem tanto guerreiros índios como soldados europeus com uma mão na cintura e outra estendida ou dobrada, sustentando uma arma. Perceba-se que a posição adotada pelos soldados franceses com suas armas de fogo descansando sobre seus ombros é muito próxima da do chefe Tupinambá. Desse modo, a diferença das imagens estaria estabelecida pelas armas e pelas roupas de cada um deles.

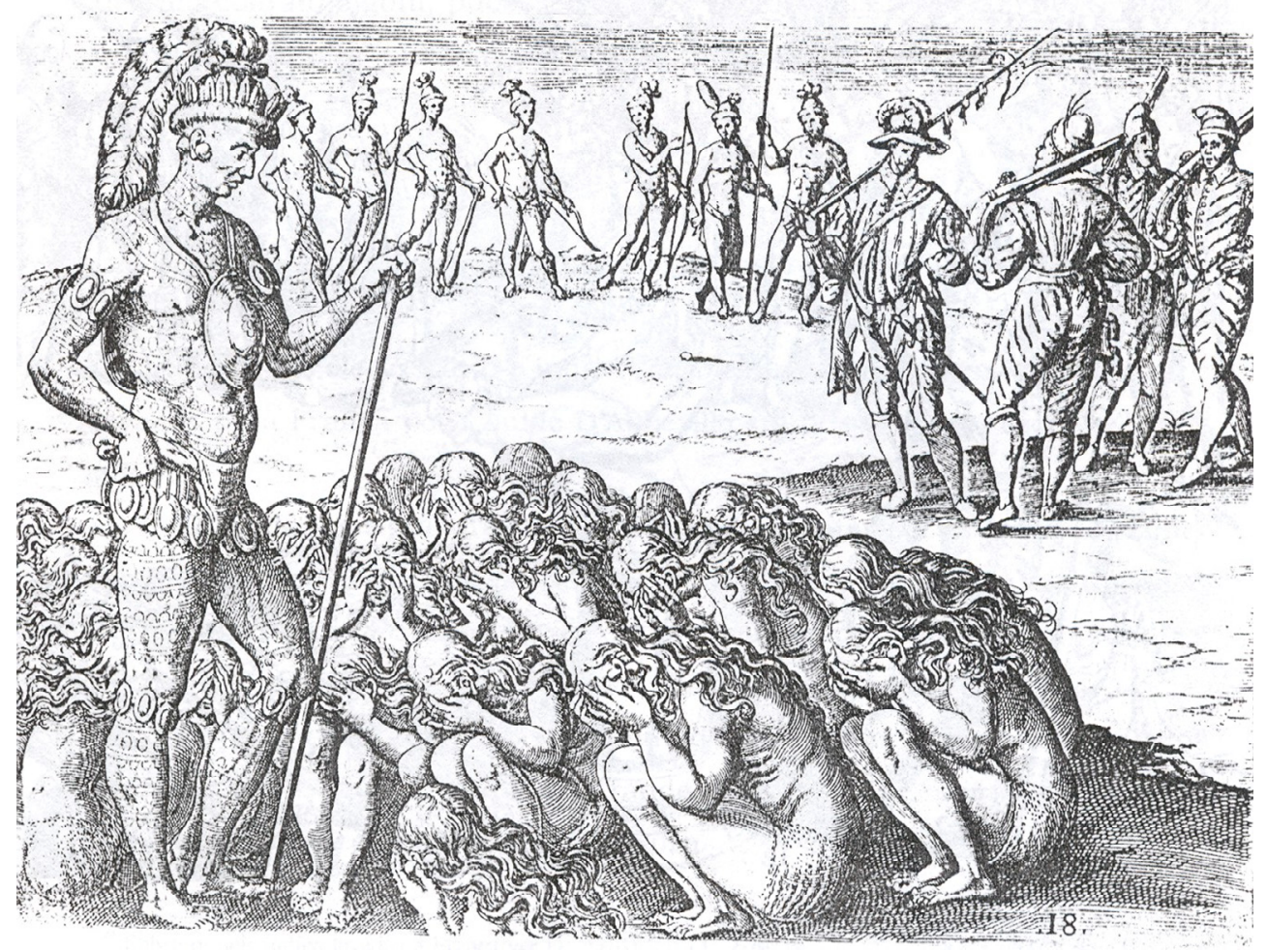

Figura 8. Theodoro De Bry. Mulierum,quarum maritivel in bello caefi,aut morbo fublati poftulata à Rege. Brevis Narratio, Gravura, 1591.

Em outra imagem em que aparece Outina sentado sobre suas pernas consultando os augures para a batalha, o rei mudou de posição, mas a postura continua reproduzida nos guerreiros índios e nos franceses dos planos de fundo. Isto se repete em outras gravuras (fig.9), indicando que a posição tem a ver não só com uma posição de importância, mas também com um estado de ânimo da figura representada, sejam estes europeus ou índios: altivo, de desafio, nobre e até de orgulho.

Ao comparar diversas gravuras sobre índios feitas por Theodoro De Bry nas Grandes Viagens sobre nativos da Virgínia, Flórida, Peru ou Brasil, percebe-se que uma pose como a do rei Outina é comum em outros índios não só da Flórida, como de 
lugares e nações diferentes, que nunca tiveram nenhum tipo de contato entre elas próprias.

Perceber a repetição das posturas entre as diversas etnias faz pensar desavisadamente que De Bry poderia ter repetido as poses dos originais nos quais se baseou. Uma leitura equivocada, que deve ser evitada, é a de pensar que, a repetição constante das imagens indicaria que os índios, efetivamente, poderiam ter adotado esse tipo de postura. A dúvida que surgiria com relação a essa afirmação, é que se tal premissa fosse verdadeira, como explicar que diferentes etnias índias separadas por milhares de quilômetros e que nunca tiveram contato algum, pudessem adotar as mesmas poses? Some-se a isso que essas posturas também são repetidas nas gravuras pelos europeus tanto franceses, ingleses, espanhóis e portugueses que aparecem nos episódios narrados nas gravuras.

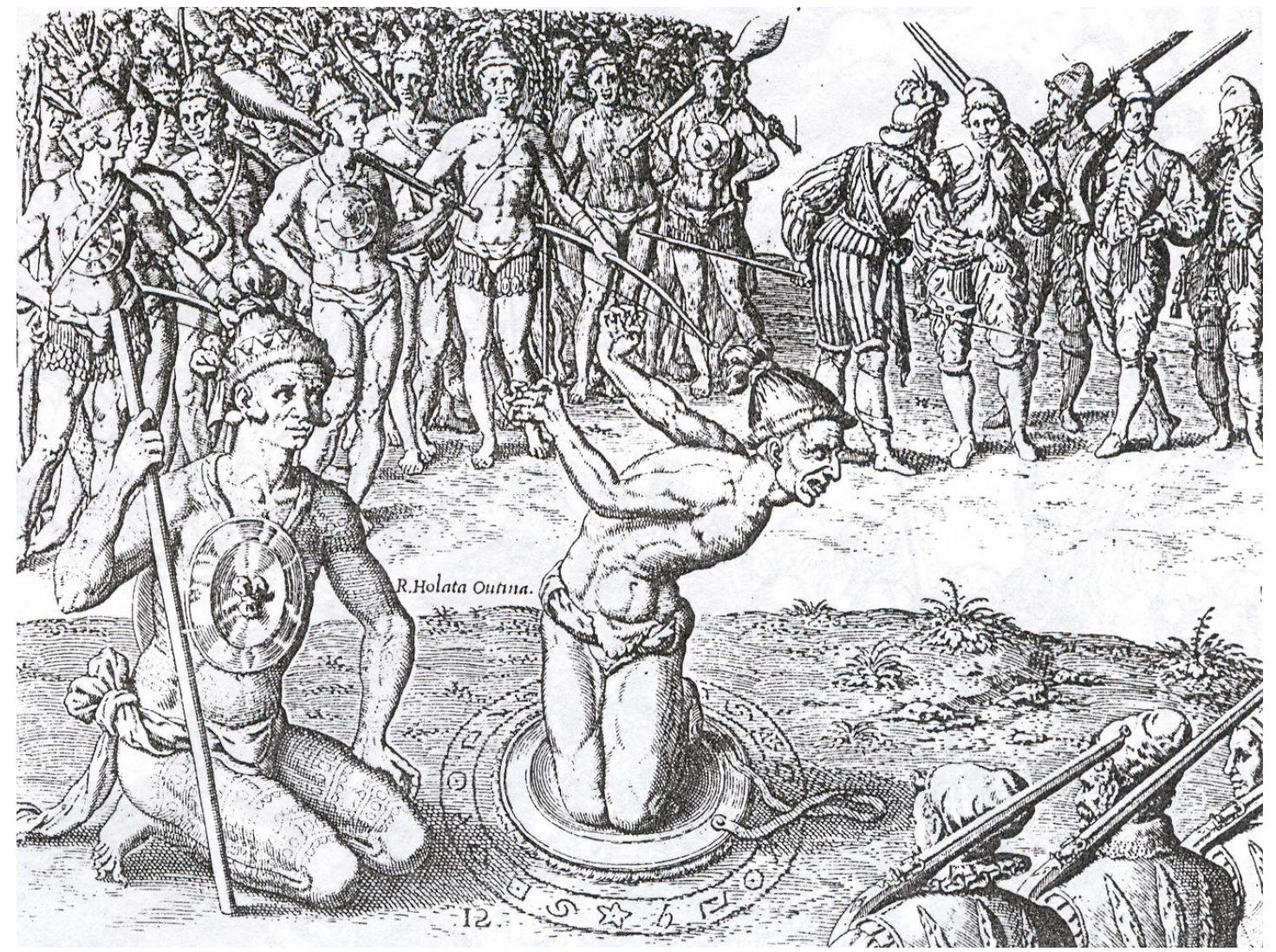

Figura 9. Theodoro De Bry. Outina adverfus hoftem exercitum ducens, de eventu Magum confulit. Brevis Narratio, Gravura, 1591.

A utilização dessa postura não é exclusiva nem original de Theodoro De Bry, podendo ser encontrada em outras representações de índios de outros artistas, como acontece em uma das gravuras de autoria de Leonard Gaulthier. Nela ele "retrata" o 
índio François ou Carypyra, um dos seis índios levados para França por Claude D’Abbeville em princípios do século XVII. ${ }^{13}$ (fig.10)

Duas das seis gravuras sobre estes índios, feitas por Leonard Gaulthier para a Histoire de la Mission des Pères Capucins en l'Isle de Maragnan et Terres Circonvoisines, permitem entender questões relativas a postura, atitudes corporais e caraterísticas do indivíduo retratado.
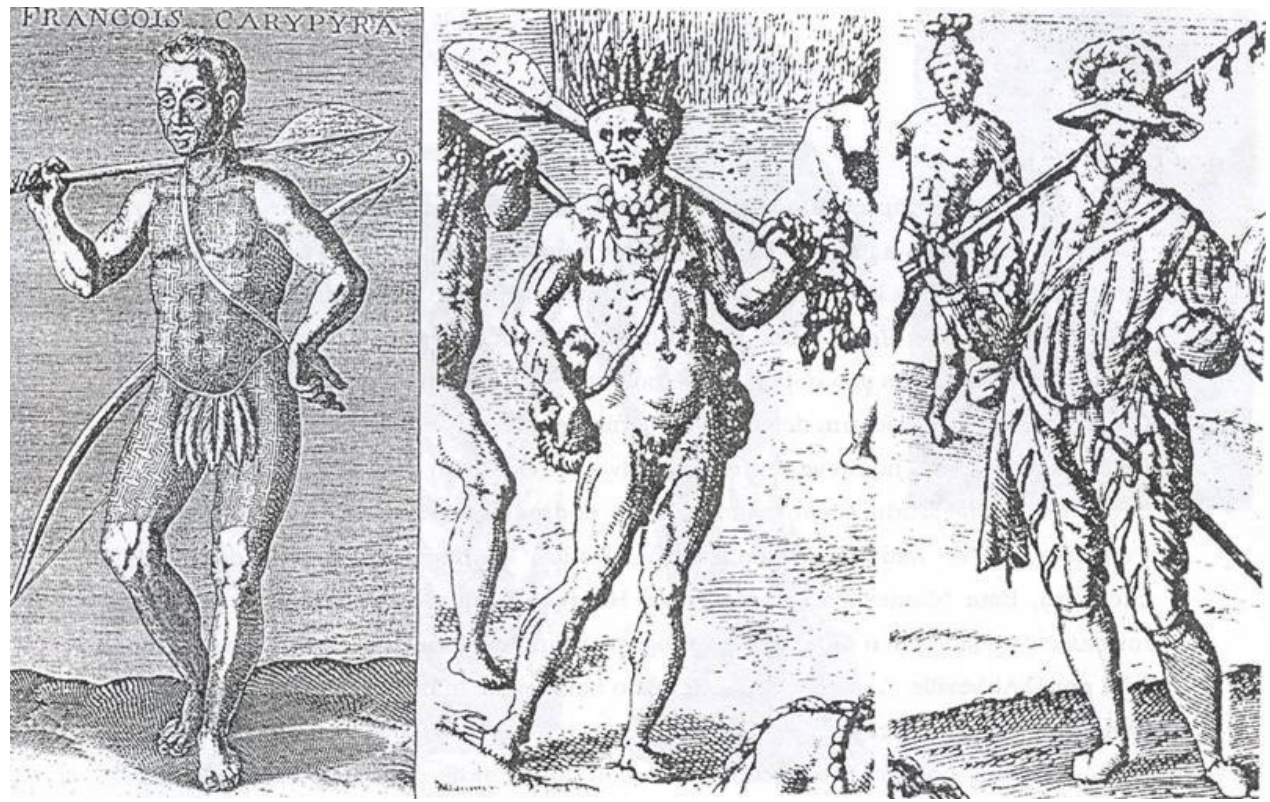

Figura 10. Detalhes índios e europeus de esquerda a direita: A) Leonard Gaulthier, François Carypyra. Claude D'Abbeville. Histoire de la Mission des Peres Capucins en l'Isle de Maragnan et Terres Circonvoisines... gravura. Paris, 1614; B) Theodoro De Bry. Chefe Tupinambá. America Tertia Pars, Gravura em cobre. Frankfurt, 1592; C) Theodoro De Bry. Detalhe do francês. Brevis Narratio, Gravura, 1591.

Carypyra ou François é representado em estado "selvagem" com suas armas, com a pele tatuada mostrando o número de inimigos mortos e devorados. Sobre ele comenta D'Abbeville:

Era, o primeiro que morreu, da nação dos Tabajaras, de uma aldeia denominada Rairi, e tinha entre sessenta e setenta anos. Além do nome de Caripira, tirado do pássaro Tesoura, e que lhe foi dado para distingui-lo dos demais, adquirira nas batalhas contra os inimigos de sua nação novos nomes e sobrenomes ... Seus nomes eram acompanhados de elogios, verdadeiros epigramas escritos não no papel, nem no bronze, nem na casca das árvores, mas na própria carne. Rosto, ventre e coxas eram o mármore e o pórfiro sôbre os quais mandara gravar a história de sua vida, com caracteres e figuras estranhas; e a sua pele mais parecia, assim uma couraça adamascada, como se pode ver de seu retrato. Ao redor do pescoço, idênticos sinais formavam um colar, de maior valor para um guerreiro do que quaisquer pedras preciosas... (cf. D' Abbeville, 1975, p.268) 
Na xilogravura de outro índio, aparece Louis Henri batizado, vestido à maneira européia, com flores em suas mãos, em uma postura gentil e menos desafiadora, sobre este D'Abbeville assinala:

O segundo índio chama-se Uaruajó. É natural da aldeia de Mocuru e filho de Uirau Pinobuí, pássaro azul sem penas na cabeça, principal do lugar. O nome de sua mãe, natural da mesma aldeia, era Uaiaeiró, penacho de penas. Tem êle vinte anos de idade mais ou menos; é muito alegre, mais claro que os outros, de rosto bem feito e mais parecido com o de um francês do que com o de um selvagem estrangeiro. De inteligência viva, começa a compreender nossa língua e nossos escritos. É uma árvore que principia dar flores e frutos e dela podemos esperar muito ... (ibidem, p.277-8. Grifos meus)

Comparando os dois retratos, pode-se perceber a mudança da postura e de atitude entre um guerreiro seminu, selvagem e o outro índio convertido ao cristianismo e vestido (fig.11).
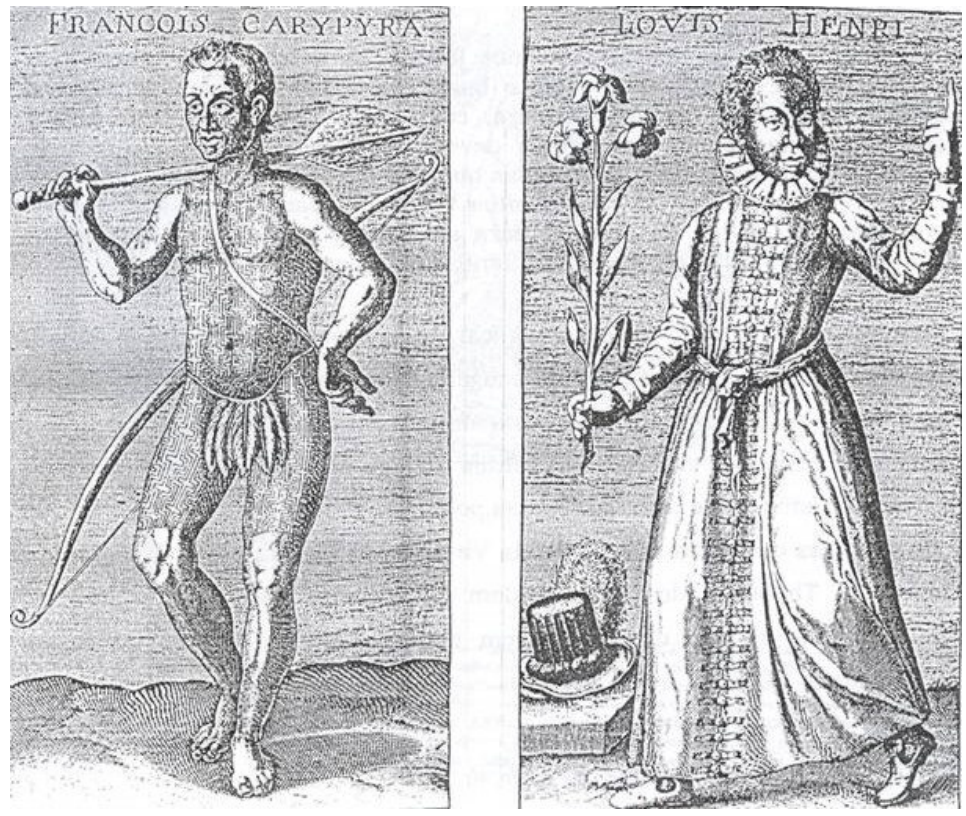

Figura 11. Leonard Gaulthier, Esquerda: François Carypyra. Direita: Louis Henri, xilogravuras 14,5 x 8,5 cm. In: Claude D’Abbeville. Histoire de la Mission des Peres Capucins en l'Isle de Maragnan et Terres Circonvoisines ... Paris: François Hubi, 1614.

François ou Carypyra aparece em movimento, com o peso do corpo sobre a perna esquerda, parecendo que vai dar um passo com a perna direita, o braço esquerdo dobrado descansa contra o corpo, e o braço direito levemente erguido, empunhando o tacape que descansa sobre os ombros; esta imagem é muito próxima do Tupinambá de De Bry. 
Carypyra é apresentado mais hostil, selvagem, imponente e orgulhoso guerreiro, enquanto a imagem de Louis Henri é mais amável e leve; o próprio rosto é mais "amigável”. Esta leitura é reforçada porque as armas Tupinambá não aparecem na gravura de Louis Henri, tendo sido substituídas por flores.

Essas imagens são importantes, pois revelam diferentes graus de civilização. $\mathrm{O}$ primeiro Carypyra foi um dos índios que morreram, recém-chegado na França e, aos olhos do gravurista, manteve seu estado selvagem e o outro, Louis Henri por ter sido batizado, evangelizado e convivido com os padres e ter aprendido os costumes franceses, seria mais civilizado, "domesticado", perdendo sua ferocidade de guerreiro. Esta "domesticação" torna Louis Henri próximo do europeu, não só nas roupas européias que o índio usa na xilogravura, mas também na própria descrição feita por D'Abbeville: “... mais claro ... de rosto bem feito e mais parecido com o de um francês do que com o de um selvagem ...”.

A gentil postura de Louis Henri e a imponente de Carypyra feitas nas xilogravuras por Leonard Gaulthier seguem os ensinamentos de Leon Battista Alberti, que considerava que os movimentos e as perturbações da alma são proporcionais aos movimentos dos membros das figuras a serem desenhadas ou pintadas:

Sejam leves os movimentos dos jovens, agradáveis, com uma certa manifestação de grandeza de alma e boa força. Sejam os movimentos dos homens dotados de bastante firmeza, com poses belas e artificiosas. Os movimentos e as poses dos velhos devem ser de cansaço; que eles se sustentem não apenas com os pés, mas também com as mãos, Cada um, pois, com dignidade, tenha os movimentos do corpo para exprimir todos os movimentos desejados da alma e, para as grandes perturbações da alma, sejam proporcionais os grandes movimentos dos membros... (Alberti, 1989, Livro Segundo, 40, p.119)

Normalmente, quando se tenta explicar ou interpretar as imagens dos índios de Theodoro De Bry, as classifica como imagens renascentistas seguindo os padrões clássicos, mas pouco se aprofunda sobre o alcance dessa conotação. A repetição das posturas em etnias e culturas diferentes causa certa inquietude, levando a comprovar a existência de convenções nas posturas.

As posturas elegantes dos índios da Virgínia, da Flórida ou do Brasil não são exclusivas de Theodoro de Bry e podem ser encontradas na arte da época, especialmente no retrato de nobres, em personagens bíblicos e nas imagens mitológicas (fig.12-3). 

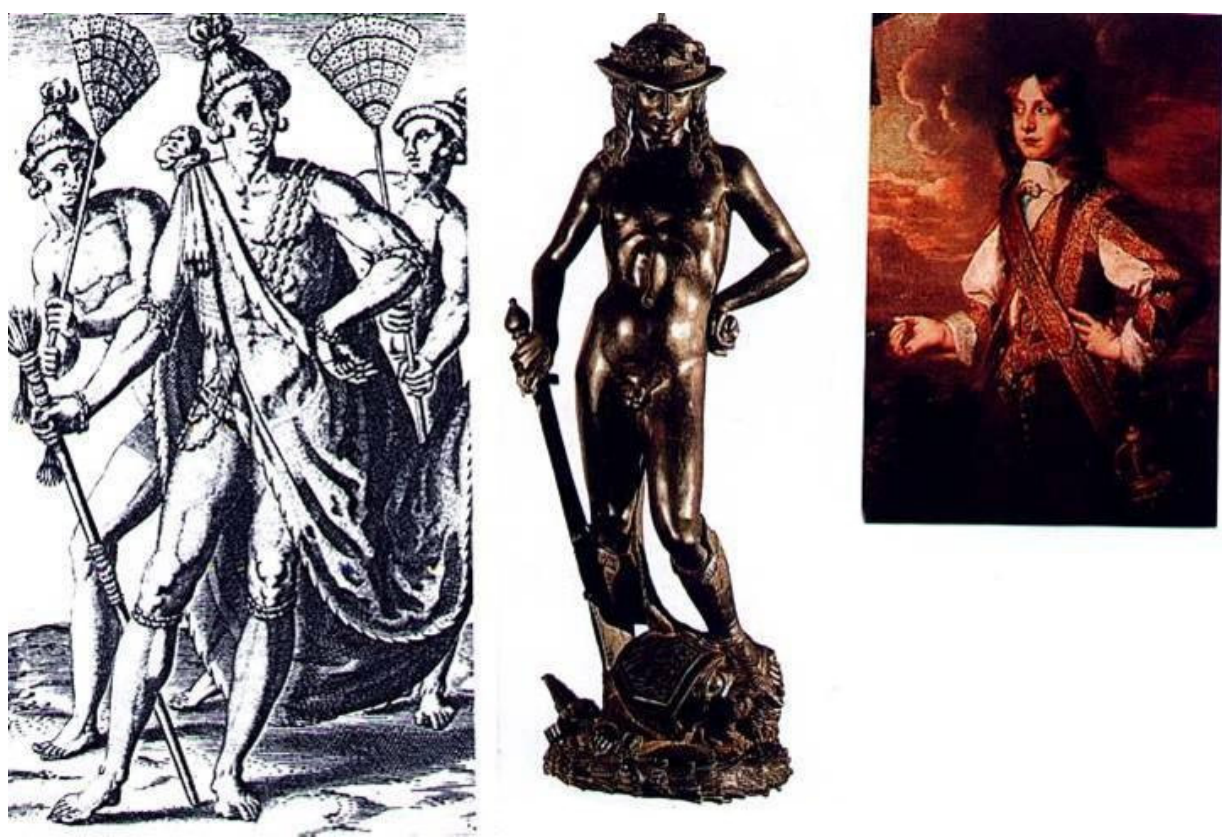

Figura 12. Detalhes de posturas. Figuras com um braço estendido e o outro recolhido sobre a cintura. Esquerda: Detalhe do rei índio da Florida. Theodoro De Bry; Regis \& Regina prodeambulatio recreandi animi gratia. Brevis Narratio, gravura, 1591. Centro: Donatello. Davi. Bonze, $159 \mathrm{~cm}$. Museu Nazionale del Bargello, Florença. 1433; Direita: Sir Peter Lely. Carlos I com James, duque de York. Detalhe do duque. Óleo sobre tela, 126,4 x 146,7 cm. Syon House, Isleworth. 1647.
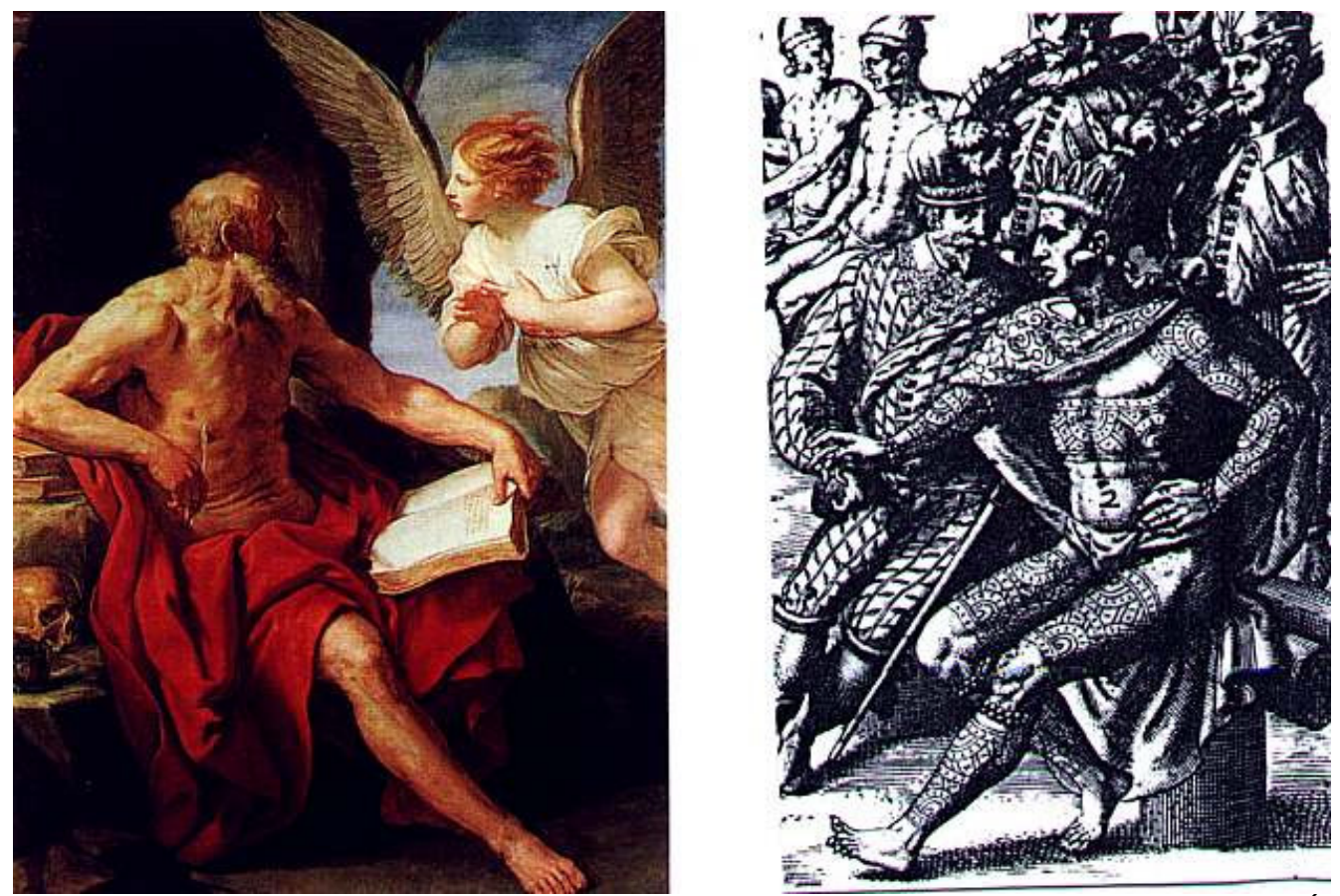

Figura 13. Detalhes de posturas. Figuras sentadas. Esquerda: Guido Reni. São Jerônimo e o anjo. Óleo sobre tela, 198 x $149 \mathrm{~cm}$. Detroit Institute of Art, Detroit. 1640-1642. Direita: Detalhe rei índio sentado Theodoro De Bry. Excubitorum focordia ut punitur. Brevis Narratio. Gravura, 1591.

A arte da Renascença toma as esculturas clássicas modelos de beleza por excelência, principalmente as figuras mitológicas. ${ }^{14}$ As posturas e as ações do corpo 
presentes nas esculturas da época romana e grega foram resgatadas na Renascença, encontrando também seu equivalente nas figuras dos índios, não só de Theodoro De Bry, como também nos gravuristas de Staden e Léry. Figuras de deuses ou atletas com seus corpos escultóricos foram reproduzidas com mudanças mínimas no corpo dos índios do Brasil e da Flórida (fig.14-5).
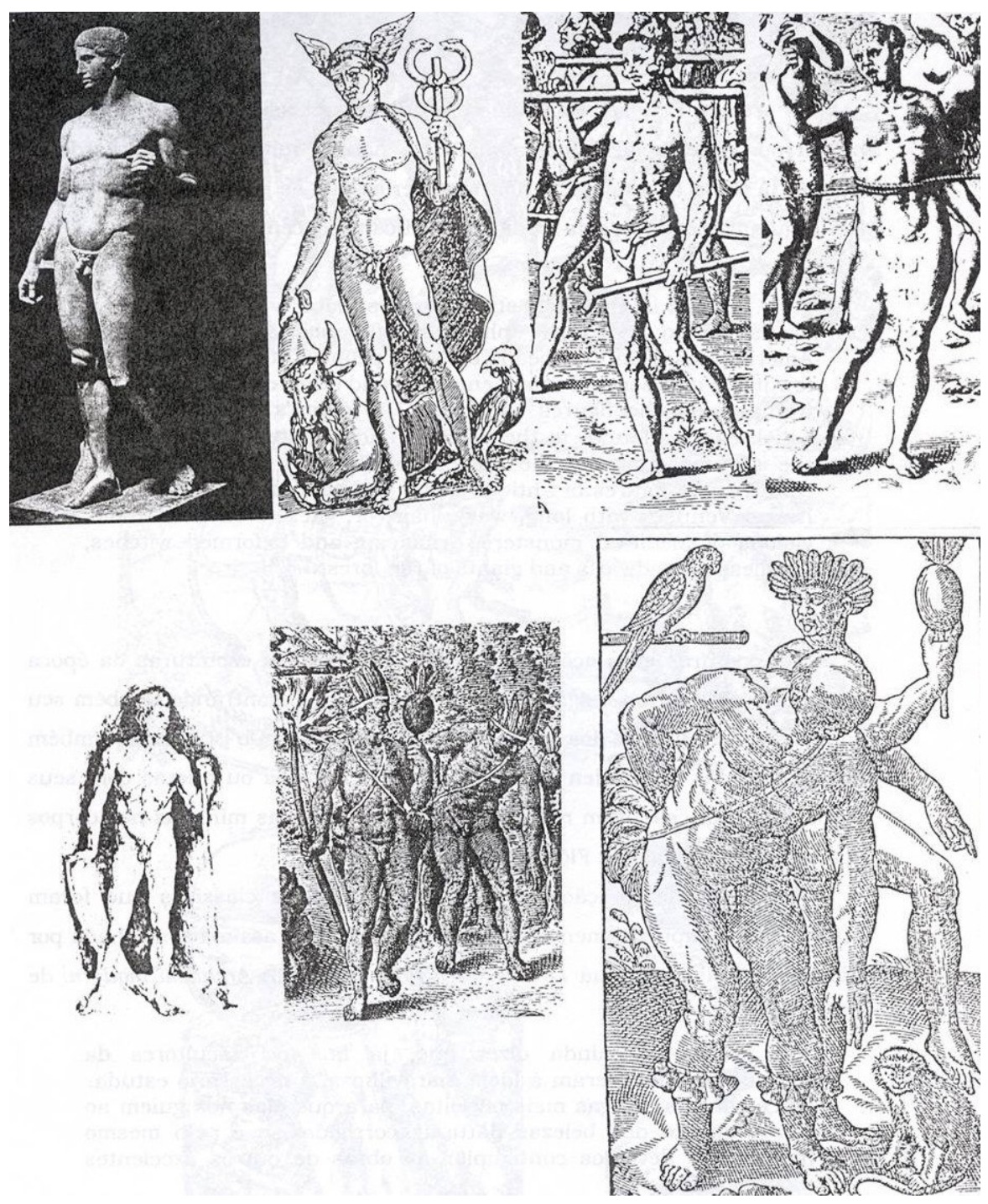

Figura 14. Superior. Esquerda a direita: A) O Doríforo. Período romano (cópia da estátua de bronze do atleta feito por Policleto de Argos cerca de 440 a.C.), Mármore, 2,12 mts de altura. Museu Nacional, Nápoles. Século I. B) Conrad Peutinger. Mercúrio. Inscriptiones sacrosanctae vetustatis. Xilogravura. Mogúncia, 1520. C) Detalhe de Índio da Florida. Theodoro de Bry. Qua pompa Regina delecta ad Regem deferatur. Brevis Narratio. Gravura, 1591. D) Detalhe vítima dos Tupinambá. Theodoro de Bry. Americae Tertia Pars, gravura, 1592. Inferior. E) Albrecht Dürer. Guerreiro nu. Desenho. Musée Bonnat, Bayonne. Século XVI. F) Tupinambás. Theodoro de Bry. Americe Tertia Pars, gravura, 1592. G) Dança de índios Tupinambás. Jean de Léry. Histoire d'une voyage fait en la terre du Bresil. Autrement Dite Americque... 4.ed. Genebra, Heritiers D’Eustache Vignon. Xilogravura 14 x 18 cm, 1600. 

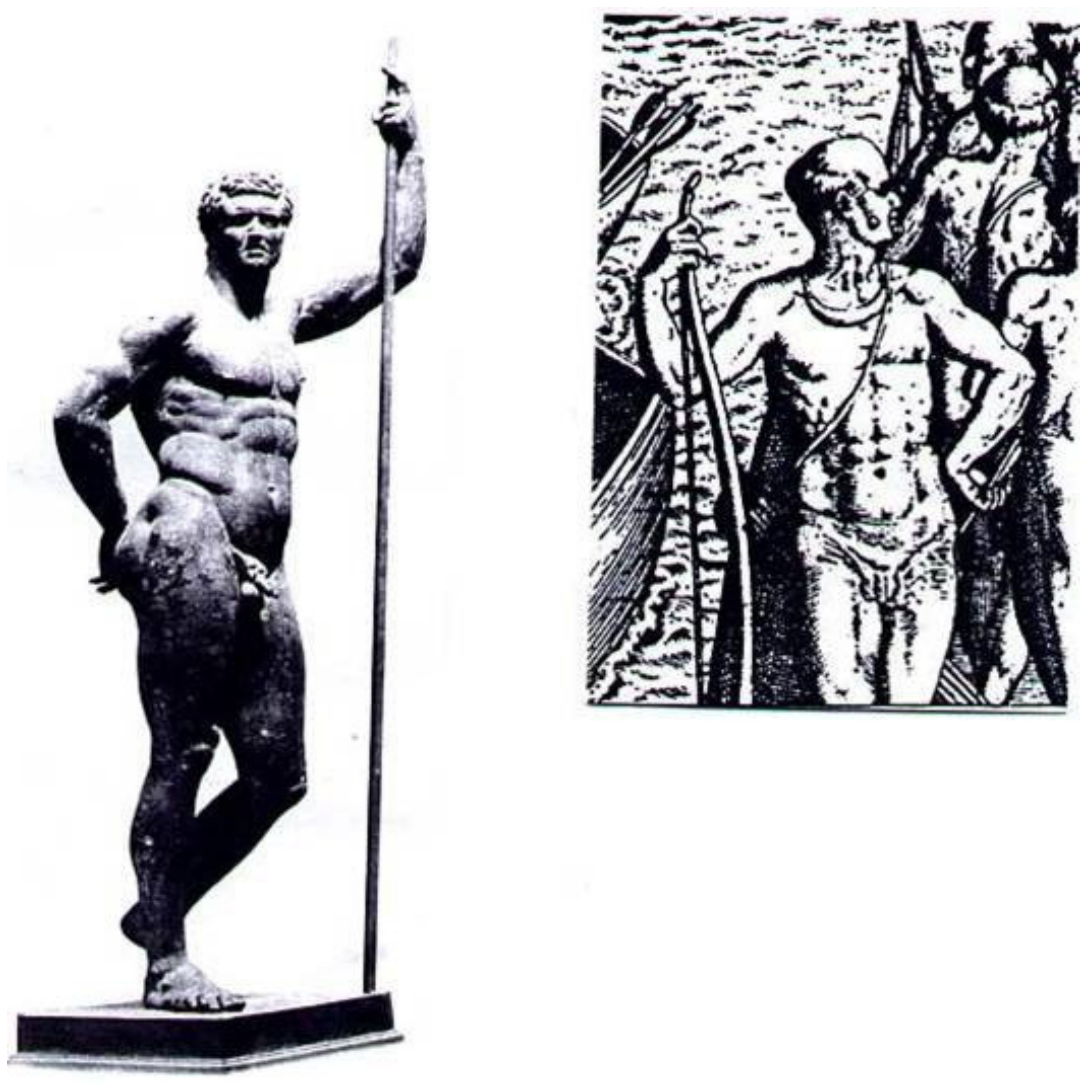

Figura 15. Esquerda: O Soberano helenístico. Bronze. Museu de Termos, Roma. Século II a.C. Direita: Detalhes de índios Tupinambá que se apóiam no arco. Theodoro de Bry. Americe Tertia Pars, gravuras, 1592.

Era tal a fascinação causada pelas as obras clássicas que foram estudadas "compulsivamente" pelos artistas, prática assim aconselhada por Gio Pietro Bellori na sua Le vite de' Pittori, Scultori e Architetti moderni de 1672:

Resta-nos ainda dizer que, já que os Escultores da Antigüidade recorreram à Idéia maravilhosa, é necessário estudar as esculturas antigas mais perfeitas, para que elas nos guiem ao conhecimento das belezas naturais corrigidas, e é pelo mesmo motivo que devemos contemplar as obras de outros excelentes mestres ... (Bellori, in Panofsky, 2000, p.154)

Precisamente nos séculos XV e XVI que muitas esculturas romanas dos séculos I a II foram encontradas na Itália. Redescobertas e desenterradas, estas esculturas representavam cópias de esculturas gregas clássicas (séculos V-IV a.C.) e helenísticas (séc. IV a.C. I a.C.), que foram tomadas como exemplo e modelo da verdadeira arte, como o ressalta Bellori nos seus escritos: 
Os gregos estabeleceram os melhores limites e proporções, e estes, confirmados ao longo dos séculos e aprovados por toda a linhagem dos Sábios, tornaram-se as leis de uma maravilhosa Idéia e da beleza suprema, a qual, permanecendo sempre uma em cada espécie, não pode ser nem um pouco alterada sem ser completamente destruída ... (ibidem, p.155)

Não são só os escritos de Bellori que enaltecem a arte antiga grega como protótipo de perfeição; na realidade, a maioria dos tratados entre os séculos XV e XVII repetiram a importância de estudar e tomar como modelo a arte antiga.

A influência da arte clássica nas imagens dos índios foi também anotada por Ana Belluzo, ao se referir à xilogravura de Jean de Léry, na qual dois índios tupinambás dançam ao som de maracás. A partir desta xilogravura Theodoro De Bry compôs sua versão sobre a Dança dos índios. Belluzzo encontra similitudes entre a postura da estátua do Discóbolo e os índios dançarinos Tupinambá de Léry:

O movimento dos índios em dança estabelece a disposição regular das partes do corpo para diferentes direções, sendo fiel ao desejo de uma forma racional e à unidade geométrica espacial. Pode-se adivinhar que o Discóbulo - um dos modelos da escultura grega antiga - empresta sugestões á rotação da figura indígena, vindo o movimento apontar para o espaço ao redor. Afinal, o artista não teria isso em mente ao relacionar as duas figuras, sugerindo uma seqüência de posições da primeira para a segunda, do frontal para o perfil, do curvado para o ereto?... (Belluzo, 2000, p.43)

Gravuras de cenas com vários índios na Americae Tertia Pars às vezes assemelham-se a estudos anatômicos de uma mesma figura que gira. Este tipo de estudo “anatômico" já aparecia na Admiranda Narratio, onde dinâmicas mostram os opostos, figuras humanas de frente, de costas, em escorço. Um exemplo é que as imagens de índios feitas por White, ao serem copiadas por De Bry, ganham retratos de costas, que nos originais não existiam (cf. Baumann, 2001, p.323-4). Ana Belluzzo esclarece que “... O princípio da divisão de todo ou da multiplicação das partes é constante. A visão de um objeto sob diferentes ângulos leva à compreensão de sua totalidade ...” (Belluzo, 2000, p.55) (fig.16). 

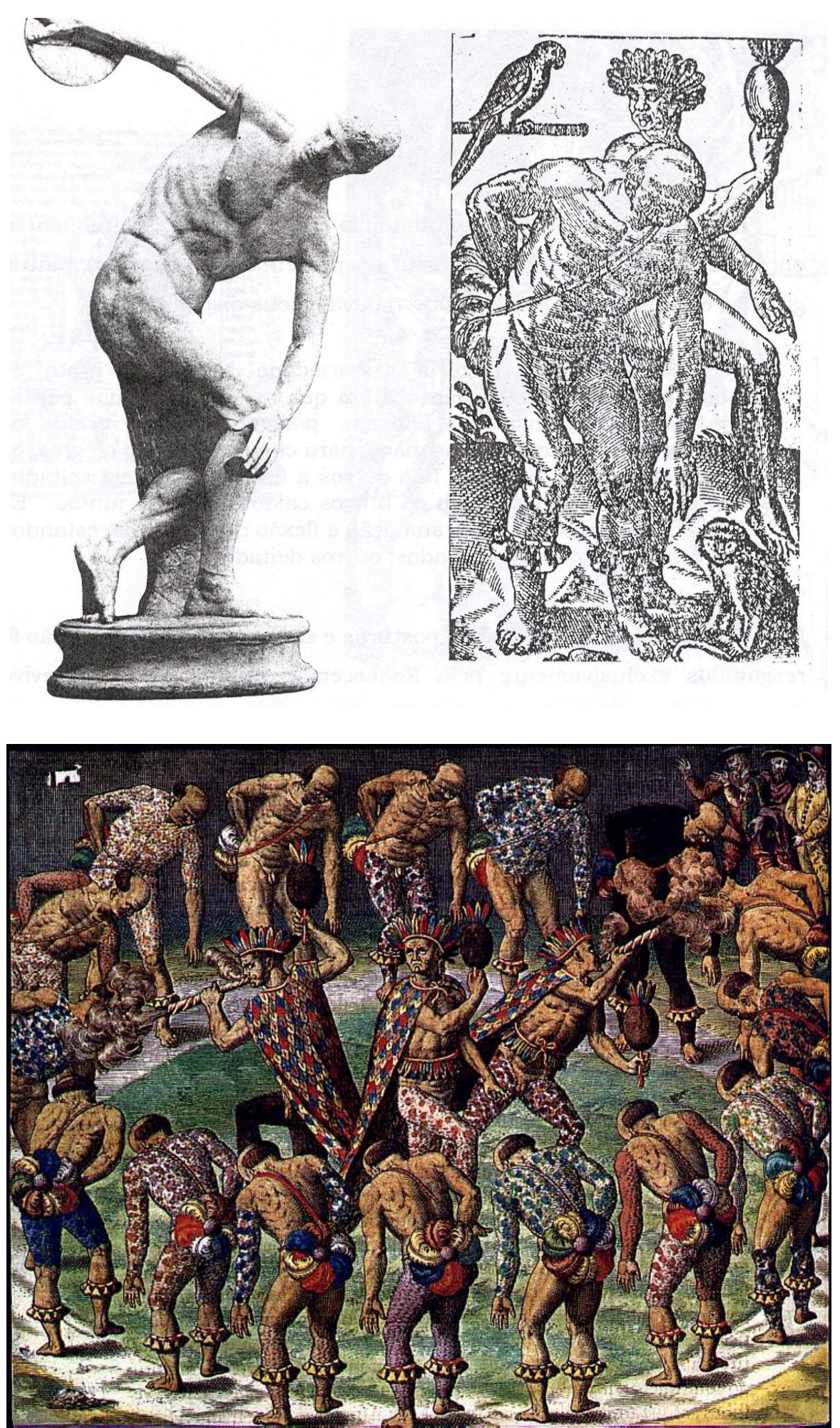

Figura 16. Superior esquerda: Discóbolo Lancellotti. Périodo Romano (cópia da escultura de Míron 450 a.C.). Mármore, com 1,25 m de altura. Museu dos Termos, Roma. Século I. Superior direita: Dança de índios Tupinambás. Jean de Léry. Histoire d'une voyage fait en la terre du Bresil. Autrement Dite Americque ... 4 ${ }^{\mathrm{a}}$. ed. Genebra, Heritiers D’Eustache Vignon. Xilogravura 14 x $18 \mathrm{~cm}, 1600$. Inferior: Dança dos Tupinambás. Theodoro de Bry. Americe Tertia Pars, gravura, 1592. 
Tais estudos do corpo, sua anatomia e sua postura são freqüentes nas obras da época e a variação nas figuras apresentada no desenho, pintura ou gravura era um conselho que Alberti dava a seus discípulos:

Em qualquer história a variedade sempre é grata e sobretudo é agradável a pintura em que os corpos e suas poses sejam bem diferenciados. Estejam, portanto, alguns eretos e mostrem toda a face, com as mãos para cima e os dedos alegres, e se apóiem em um dos pés. Nos outros a fisionomia esteja voltada para sentido contrário, com os braços caídos e os pés juntos. E dessa forma cada um exibe sua ação e flexão de membros, estando uns sentados, outros ajoelhados, outros deitados... (Alberti, 1989, p.113).

No entanto, os modelos das posturas e composições clássicas não foram resgatados exclusivamente pela Renascença; muitos deles sobreviveram durante toda a Idade Média, embora acontecendo uma separação entre os temas e os motivos clássicos, tal como afirma Panofsky:

Sempre que a imagem clássica, ou seja, a fusão de um tema clássico com um motivo clássico, foi copiada durante o período carolíngio de assimilação febril, tal imagem clássica foi abandonada tão logo a civilização medieval chegava ao seu auge, para não ser reaproveitada até o Quatrocentos italiano ... (Panofsky, 2002, p.81).

A partir das imagens mitológicas clássicas os artistas da Renascença produziram os cânones para compor os corpos. A beleza das figuras clássicas estava relacionada com a simetria, isto é, a relação harmoniosa das partes com o todo. Poder expressivo e beleza do corpo humano foram dois ideais que os artistas do Renascimento encontraram realizados na arte clássica (ibidem, p.310).

Uma escultura da época helenística vai marcar a arte Renascentista do século XVI: o Apolo de Belvedere. Escultura em mármore, com 2,24 metros, feita por Leócares aproximadamente em 340 a.C. ${ }^{15}$ (fig.17), descoberta em Roma por volta de 1496, foi considerada por artistas como Michelangelo, Dürer e Ghirlandaio o protótipo da beleza, o cânone perfeito. 


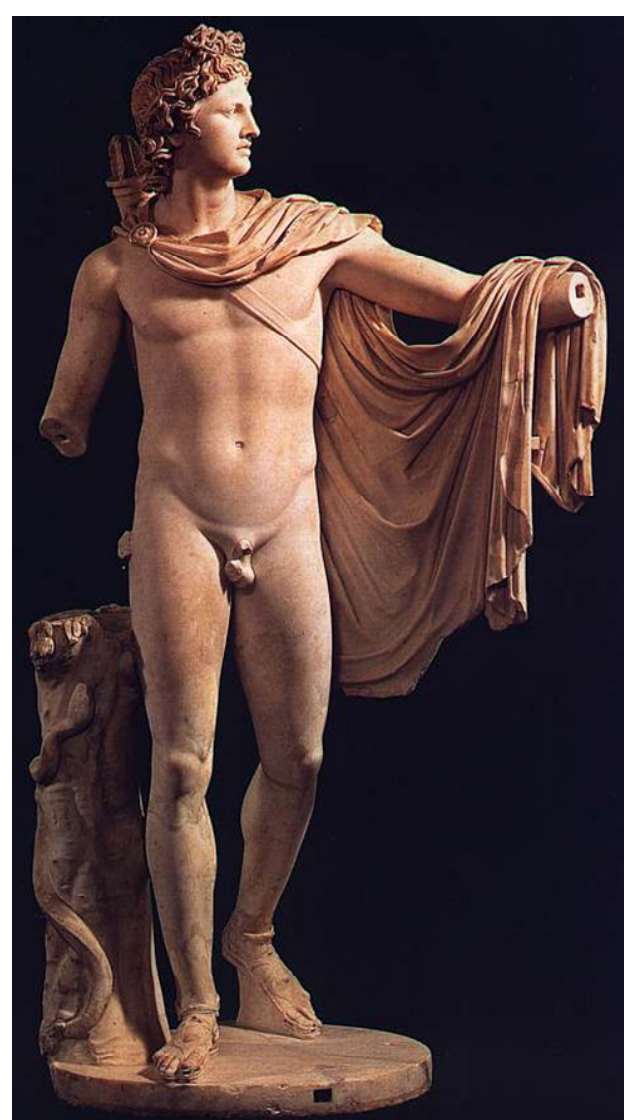

Figura 17. Leócares. Apolo de Belvedere (Cópia romana do século I). Mármore, 2,24 metros. Museu do Vaticano, Roma, 340 a.C.

O Apolo de Belvedere exerceu grande influência em Dürer, chegando a ser conhecido por ele através dos desenhos italianos na época em que procurava pelo cânone ideal, nunca diretamente. Dessa forma, fazem sentido as palavras de Panofsky: “... Dürer não foi ao encontro do antique, mas o antique é que foi ao encontro de Dürer - através de um intermediário italiano ..."

Um Mercúrio romano descoberto em Augsburgo, depois de 1500, que se tornara propriedade de Conrad Peutinger, também seria um modelo para os artistas alemães nessa procura (ver figura inferior esquerda 18).

Dürer procurou o cânone ideal nos Apolos, como se pode comprovar em muitas das suas obras; sua dedicação ao estudo o levou a repetir insistentemente a postura do Apolo nos desenhos e pinturas. Talvez a imagem mais famosa que manteve as características apolíneas (Panofsky, 1995, p.274) seja a famosa gravura de Adão e Eva (ver figura 18 superior direita). 


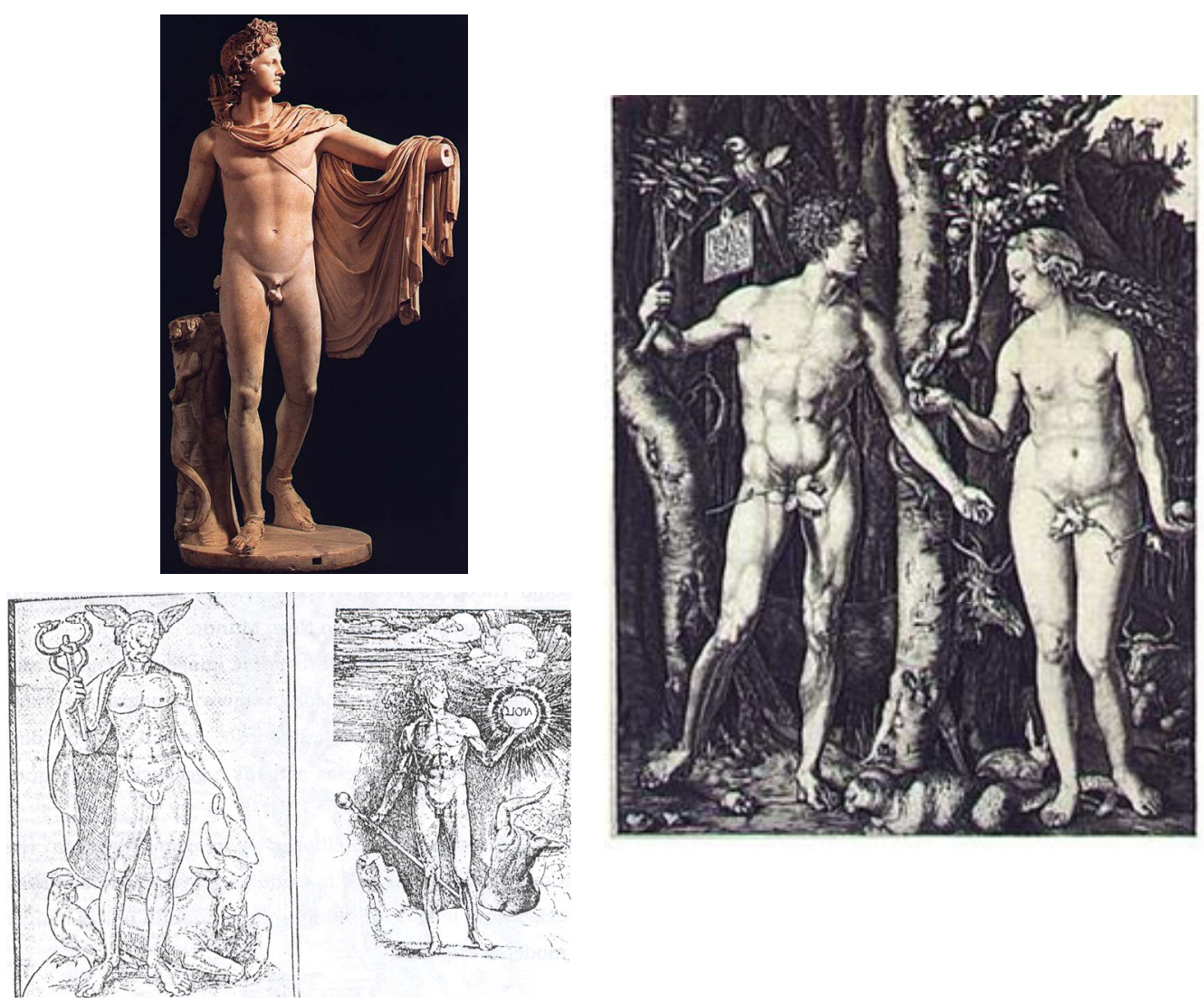

Figura 18. Superior esquerda: Leócares. Apolo de Belvedere (Cópia romana do século I). Mármore, 2,24 metros. Museu do Vaticano Roma, 340 a.C. Superior direita: Albrecht Dürer. Adão e Eva ou Queda do homem. Gravura sobre chapa de cobre 24,8 x 19,2 cm, Museu Albertina, Viena, 1504. Inferior esquerda: Conrad Peutinger. Mercúrio. Inscriptiones sacrosanctae vetustatis. Xilogravura. Mogúncia, 1520. D. Albrecht Dürer. Apolo-Sol e Diana. Desenho. British Museum, Londres século XVI.

O Adão, do mesmo modo que as representações mitológicas, apóia seu peso em uma das pernas, enquanto a outra perna permanece um pouco fora do corpo; um braço aparece recolhido, enquanto o outro aparece estendido. Uma citação de Alberti faz lembrar a postura deste Adão:

É preciso ter presente que em todas as suas poses o homem usa todo seu corpo para sustentar a cabeça, o mais pesado de todos os membros. Quando ele se apóia em um pé, esse pé fica sempre perpendicular à cabeça, como a base de uma coluna. Quase sempre a fisionomia de quem se mantém ereto se volta para a mesma direção do pé. Tenho observado que os movimentos da cabeça são sempre de tal forma que abaixo sempre há alguma parte a sustentá-la, tão grande é seu peso; ou também, o membro que corresponde ao peso da cabeça fica esticado na parte contrária, como um braço de balança... (Alberti, 1989, Livro Segundo, 43, p.117) 
As posturas idealizadas na gravura de Adão e Eva encontram-se repetidas nos índios de Léry e nos índios do frontispício da Americe Tertia Pars De Bry (fig.19). As conexões entre os cânones de Dürer e Theodoro de Bry não são simples coincidências: De Bry recebeu a influência de Dürer na Alemanha por intermédio de Etienne Delaune.
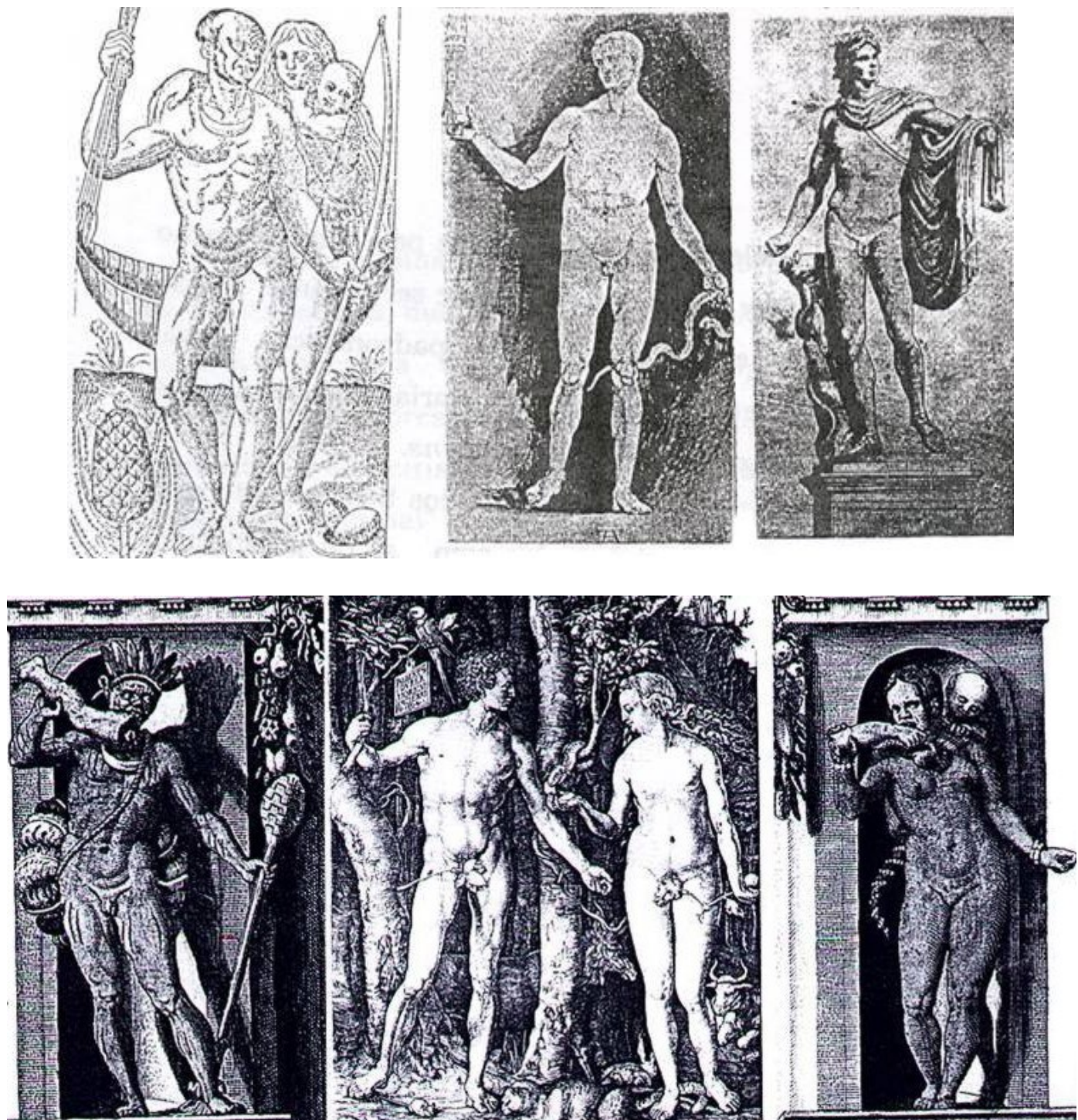

Figura 19. Superior de esquerda a directa: Família de Tupinambás. Jean de Léry. Histoire d'une voyage fait en la terre du Bresil. Autrement Dite Americque ... 4.ed. Genebra, Heritiers DEustache Vignon. Xilogravura 14 x $18 \mathrm{~cm}$, 1600. Albrecht Dürer. Esculápio ou Apolo Médico. Desenho. Kupferstichkabinett, Berlin. Séc. XVI. C. Apolo de Belvedere. Desenho do Codex Escurialensis, $\mathrm{f}^{\mathrm{o}} 64$ Viena. Inferior de esquerda a direita: Detalhe índio tupinambá do Frontispício. Theodoro de Bry. Americae Tertia Pars, gravura, 1592. Albrecht Dürer. Adão e Eva ou Queda do homem. Gravura sobre chapa de cobre 24,8 x 19,2 cm, Museu Albertina, Viena, 1504. Detalhe índia tupinambá do Frontispício. Theodoro de Bry. Americae Tertia Pars, gravura, 1592.

Os discípulos de Dürer herdaram os novos cânones que foram difundidos por toda Europa. Os artistas usaram os cânones do mestre alemão como adaptação e correção para compor as figuras humanas de suas obras - os cânones se converteram em 
squematas, explicados de uma forma vulgar em "manequins"; isto em parte também explica a presença de formas repetidas entre diferentes artistas, bem como das formas andróginas, esquemas que originalmente eram de mulher, podiam passar para homem ou vice-versa, dependendo da necessidade dos artistas.

Finalmente, é importante ter claro que o artista não "pintava o que via", ou seja, o contato com o mundo natural é relativo. Ainda na Renascença, quando esta idéia começa a ganhar destaque, tal observação não é direta, já que se fazia através dos cânones, isto é, a partir de fórmulas esquemáticas que triunfaram e se converteram em convenções. Foi a partir delas que um artista como Theodoro de Bry representou o índio, não importando que ele nunca tivesse visto um nativo do Novo Mundo.

Por Theodoro de Bry ser editor suas imagens atendem mais ao público em geral, não tendo nenhum compromisso etnográfico. Mas por ser um artista talentoso, esforçado e cuidadoso, copiou muitos destes detalhes "etnográficos" "registrados" pelos artistas e gravuristas em que baseou suas imagens.

Isso não o impediu de "melhorar" as imagens seguindo critérios de editor, aumentando detalhes e fazendo as gravuras mais interessantes a um público exigente e letrado (Mukerji, 1983, p.66), adaptando e criando novas imagens diferentes de seus modelos originais.

\section{Conclusão}

Para confeccionar as gravuras dos primeiros volumes das Grandes Viagens, Theodoro de Bry baseou-se nas aquarelas inéditas de John White sobre os Algonquinos (Admiranda Narratio) e nas pinturas sobre a tribo dos Timucuas, feitas por Jacques Le Moyne de Morgues (Brevis Narratio). Estes artistas marcaram profundamente o estilo de De Bry, no tratamento dos fundos e da figura humana.

As imagens de White e de Morgues, como assinala Belluzo, são importantes porque “... dão conta de modelos de sintaxe visual e de observações etnográficas que iriam marcar o projeto de De Bry ...” (Belluzo, 2000, p.54). Quando comparadas as gravuras de De Bry aos modelos de Morgues e White, as modificações entre eles são mínimas. Porém, no caso das gravuras da Americae Tertia Pars, quando comparadas aos modelos originais, as xilogravuras das obras de Staden e Léry, a sofisticação do flamengo é evidente. 
A partir dos esquemas estabelecidos e apreendidos pela sua formação como gravador e desenhista, De Bry teve a capacidade de ser original, devido ao seu esforço de dar unidade e estabelecer uma padronização visual sofisticada das gravuras de diferentes relatos e de variados artistas que serviram de modelo e base para a coleção Grandes Viagens.

Os elementos que dão unidade às estampas estão relacionados basicamente com dois aspetos primeiro: os fundos, mais elaborados com uso da perspectiva preenchendo o espaço em volta das figuras, que nas xilogravuras originais a maioria das vezes permanecia em branco; e segundo: no uso de cânones elaborados para os corpos dos índios, permitiram uma identidade visual.

No caso da Americae Tertia Pars os elementos originais de De Bry não se restringem aos corpos ou aos fundos; a presença e o destaque das mulheres nos diferentes episódios das gravuras e os detalhes cruéis, minuciosos e mórbidos da preparação e consumo de carne humana, nas cenas da antropofagia, alcançaram a apoteose do horror com o flamengo, impressionaram e chocaram sua sociedade. De Bry, ao combinar o exótico, o erótico e o macabro das cenas aos cânones renascentistas, converteu sua obra em um referencial para artistas que deveriam representar índios e cenas antropofágicas.

Os corpos dos índios renascentistas de Theodoro De Bry mostram a nudez como estado natural ideal, da mesma forma que os índios das gravuras do relato de Jean de Léry (1578), como anota Belluzzo: “... o estado natural é tido como verdade essencial, diferente do artificialismo da sociedade européia, apreciando a simplicidade do nu como virtude ..." (ibidem). Nas gravuras de De Bry, o pudor, nas poucas vezes que é registrado, é manifestado pelo alemão Hans Staden, nunca pelos índios.

O corpo enrugado e decaído das índias velhas corresponderia a um reflexo do seu interior, da sua alma. Seria um chamado de alerta às práticas selvagens, isto é, consumir carne humana levaria à deterioração do corpo e a perda da alma. Porém também é uma reflexão à transitoriedade da existência, à finitude das coisas materiais.

Contudo, estas modificações do corpo não correspondem apenas a questões morais, mas também à crise surgida no século XVI, que questionou alguns conceitos da Renascença, especialmente os rígidos cânones matemáticos, expressão da beleza perfeita para representar o corpo.

A esses conceitos o Maneirismo respondeu com seus corpos mais alongados (de 10 cabeças, o "normal" eram ser de 8), com as famosas figuras "serpentinas ou 
serpentinatas" (Baumann, 2001, p.310-3), corpos em forma de "S" ou "língua de fogo" (Panofsky, 2000, p.75), corpos torcendo-se e curvando-se, recusando a "tirania" da beleza matemática, a perspectiva, e voltando a uma forma de compor medieval agrupando formas no primeiro plano e a seguir o instinto, o sentimento mais que a razão ${ }^{17}$.

\section{REFERÊNCIAS BIBLIOGRÁFICAS}

ALBERTI, L. B. Da Pintura. Campinas: Editora da Unicamp, 1989, Livro II, 44.

ARGAN, G. C. Clássico Anticlássico. O Renascimento de Brunelleschi a Bruegel. São Paulo: Companhia das Letras, 1999.

BARASCH, M. Teorías del Arte. De Platón a Winckelmann. Madrid: Alianza Editorial, 1999.

BAUMANN, T. Thesaurus de Viagens. Theodoro de Bry: identidade e alteridade na iconografia do século XVI. Niterói, 2001. Tese (Doutorado em História) - PPGH, UFF. $2 \mathrm{v}$.

BELluZZO, A. M. de M. O Brasil dos Viajantes. $3^{\text {a }}$ ed. Rio de Janeiro: Editora Objetiva/Metalivros, 2000.

BUCHER, B. Icon and Conquest. A structural analysis of the illustrations of de Bry's Great Voyages. Chicago and London: The University of Chicago Press, 1981.

CARDUCHO, V. Diálogos de la Pintura. Su defensa, origen, esencia, definición, modos y diferencias. Edición, prólogo y notas de Francisco calvo Serraller. Madrid: Ediciones Turner, 1977, Diálogo Quarto.

D’ ABBEVILLE, C. História da Missão dos padres Capuchinos na Ilha do Maranhão e terras circunvizinhas. Belo Horizonte: Ed. Itatiaia; São Paulo: Ed. da Universidade de São Paulo, 1975.

DEL PRIORE, M. Esquecidos por Deus: Monstros no mundo Europeu e IberoAmericano. (Séculos XVI-XVIII) São Paulo: Companhia das Letras, 2000.

EISENSTEIN, E. L. A Revolução da Cultura Impressa. Os primórdios da Europa Moderna. São Paulo: Editora Ática, 1998.

GOMBRICH, E. H. Norma e Forma. São Paulo: Martins Fontes, 1990. . Arte e Ilusão. Um estudo da psicologia da representação pictórica. $3^{\mathrm{a}}$ ed. São Paulo: Livraria Martins Fontes, 1995. 
GRUPIONI, L. D. B. Índios no Brasil. São Paulo: Secretaria Municipal de Cultura, 1992.

HAUSER, A. Maneirismo, a crise da renascença e o surgimento da arte moderna. São Paulo: Editora Perspectiva, 1993.

LAUDONNIÈRE. Le Théâtre du Nouveau Monde. Les Grands Voyages de Théodore De Bry. Paris: Gallimard, 1992.

LÉRY, J. D. Viagem à Terra do Brasil. Belo Horizonte: Editora Itatiaia; São Paulo: Ed. da Universidade de São Paulo, 1980.

LUINS, W. M. Jr. Prints and visual communication. Cambridge: The MitPress, 1982.

MASON, P. Infelicities. Representation of the Exotic. Baltimore: The Johns Hopkins University Press, 1998.

MONTAIGNE, M. De. Ensaios. Rio de Janeiro/Porto Alegre/São Paulo: Editora Globo, 1961.

MUKERJI, C. From Graven Images. Patterns of Modern Materialism. New York: Columbia University Press, 1983.

PANOFSKY, E. Vida y arte de Alberto Durero. Madrid: Alianza Forma, 1995. . Idea: A Evolução do conceito de Belo. São Paulo: Martins Fontes, 2000. . Significado nas Artes Visuais. $3^{\mathrm{a}}$ ed. São Paulo: Editora Perspectiva, 2002.

REALE, G. e ANTISERI, D. História da Filosofia. Antigüidade e Idade Média. São Paulo: Editora Paulus, 1990. VOL.I.

STADEN, H. Viagem ao Brasil. Versão do texto de Marburgo, de 1557. Publicações da Academia Brasileira. Rio de Janeiro: Officina Industrial Graphica, 1930.

CHICANGANA-BAYONA, Yobenj Aucardo. From Belvedere's Apollo to the Tupinambá Warrior: Ethnography and Renaissance conventions. História, São Paulo, v. 25, n. 2, p 15-47, 2006.

Abstract: The article begins with the presentation of Theodore de Bry's (15281598) Great Voyages Collection, and, in the second part, analyzes its ethnographic scope and the application of Renaissance art theory used in the Americae Tertia Pars (1592) engravings of the Tupinambá indians.

Keywords: Tupinambá, Theodore de Bry, engravings, Renaissance, Great Voyages, americae tertia pars, ethnography, classic canons.

Artigo recebido em 09/2006. Aprovado em 12/2006.

\section{NOTAS}


1 Conferência ministrada para o pré-grado e a pós-graduação em História da Universidade Estadual Paulista (Unesp) - Sede Franca em 2 de maio de 2006. Esta reflexão forma parte da pesquisa iniciada com a tese de doutorado em História "Imago Gentilis Brasilis. Modelos de Representação Pictórica do índio. Século XVI" defendida na Universidade Federal Fluminense (UFF) em 2004.

* Professor em dedicação exclusiva Escola de História da Universidad Nacional de Colombia, Sede Medellín. Medellín (Antioquia), Colômbia. Doutor em História pela Universidade Federal Fluminense.

${ }^{3}$ Um excelente trabalho sobre Theodoro de Bry é a Admirranda Narratio, apresentado em forma de roteiro de viagem, é Baumann, 2001. Tese (Doutorado em História) - PPGH, UFF. 2 v.

${ }^{4}$ Mukerji, 1983, p.57-8. Sobre a ampliação do público leitor, ver Capítulo 4. A Expansão da República das Letras (Eisenstein, p.109-25).

${ }^{5}$ Como huguenote fervoroso, Theodoro de Bry sempre teve interesse em ilustrar obras que registrassem as atrocidades cometidas pelos espanhóis católicos contra os protestantes e contra os índios do Novo Mundo.

${ }^{6}$ Aqui concordando com a Professora Ana Belluzo “... De acordo com códigos estéticos da época, as figuras humanas não se distinguem por traços faciais e raciais, mas pela ornamentação e pelas práticas ..." (Belluzzo, in: Grupioni, 1992, p.54).

7 "Não sabiam bem o que pensar de mim, se eu era portuguez, ou si era francez. Disseram-me que si tinha barba vermelha, como os francezes, também tinham visto portuguezes com igual barba, mas elles tinham geralmente barbas pretas ..." (Staden, 1930, p.105).

${ }^{8}$ Alberti, 1989, p.119. Uma idéia similar também está presente no tratado de pintura do século XVII de Vicente Carducho: “... no tendrá el mismo rostro, ni las mismas facciones, colores y miembros, regularmente hablando, el que fue santo y piadoso, que el que fue iniquo, cruel y tirano; no la doncella vergonzosa, como la meretriz deshonesta: pues en el Derecho en un delito que se imputa a dos, presume mas culpa en el rostro y talle feo, que en el que le tiene mas hermoso y perfecto ..." (Carducho, 1977, p.183).

${ }^{9}$ Montaigne, 1961, Livro I, Cap. XXXI. Dos canibais, p.261.

${ }^{10}$ Sobre as origens do neoplatonismo na Antigüidade consultar Reale, \& Antiseri, 1990, v.I, p.338-55. Sobre o neoplatonismo nos séculos XV-XVI, consultar o v.II - Do humanismo a Kant.

${ }^{11}$ Dürer é um artista muito importante, nesta pesquisa temos nos deparado com sua obra em diversas oportunidades, acredito que seu aporte e influência direita ou indireitamente sobre os artistas renascentistas e suas obras sobre os ameríndios resultaria numa pesquisa fascinante.

${ }^{12}$ Um excelente estudo sobre a vida de Dürer é Panofsky, 1995. Especificamente sobre Dürer como teórico conferir o cap.VIII, p.253-92.

${ }^{13}$ Sobre os seis índios levados a França ver D' Abbeville, 1975. Cap. LVII. Da morte em França de três índios Tupinambás; Cap. LVIII. Dos três índios tupinambá que ainda vive; Cap. LIX. Do batismo dos três índios; Cap. LX. De como, após o batismo, foram êsses três índios conduzidos em procissão e da confirmação que lhes foi dada, Cap. LXI. Como Deus visitou os três índios depois de batizados, p.26784.

${ }^{14}$ Bernardette Bucher já tinha assinalado de forma genérica que as gravuras feitas por De Bry seguiam convenções da tradição artística renascentista: ... One is immediately struck by the inability of the European draftsmen to grasp the physical differences that distinguish Amerindians from Europeans or other peoples. If it were not for a few items of dress and ornamentation, and other exotic details, one would think the figures came from an artist's anatomy plates, which cam be found in the painting and sculpture of that time - the statues adorning the palaces of the end of the sixteenth century, the figures of antique gods, portraits of Roman athletes, Italian Venuses with long, wavy, hair; or, at the other extreme, visions of medieval monsters, grimacing and deformed witches, headless men, dwarfs and giants of the forest ... (Bucher, 1981, p.32).

${ }^{15}$ Hoje no Museu do Vaticano encontra-se uma cópia romana do século I d.C.

16 “... não há um único caso em que se possa mostrar que Dürer se baseou diretamente no antique, seja na Alemanha, Veneza ou Bolonha. Encontrou o antique apenas - segundo seu próprio testemunho - onde esse já fora revivido durante gerações: na arte do Quatrocentos italiano, onde o deparou sob uma forma alterada segundo os padrões da época, mas, por isso mesmo, compreensível para ele. Se nos é dado falar por meio de um símile: defrontou a arte clássica da mesma maneira que um grande poeta, que não entenda grego, pode encarar as obras de Sófocles. Também o poeta terá que confiar numa tradução; mas isso não o impedirá de apreender o significado de Sófocles mais amplamente que o próprio tradutor" (Panofsky, 2002, p.366-7).

${ }^{17}$ Sobre o Maneirismo Conferir Hauser, 1993; Argan, 1999; Panofsky, 2000; Gombrich, 1990. 